\title{
PREVALENCE OF OCCUPATIONAL HAZARDS AMONG MENTAL HEALTH NURSES IN FEDERAL NEURO-PSYCHIATRIC HOSPITAL (FNPH), CALABAR, CROSS RIVER STATE
}

\author{
Dr. Umoh, Edet Okon and Iwok, Enewan Udofia \\ DOI: 10.47760/cognizance.2021.v01i07.001
}

Abstract: This study was conducted to assess prevalence of occupational hazards and illnesses among mental health Nurses in Federal Neuropsychiatric Hospital, Calabar, Cross River State. Three research questions were raised and one hypothesis formulated to direct the course of the study. The study adopted cross-sectional descriptive survey design to study 87 mental health nurses who were selected from the Hospital using stratified random sampling technique. Instrument for data collection was a self-structured questionnaire designed in consonance with the study's objectives. The validity of the instrument was ensured and high reliability coefficient was obtained for the respective variables of the study. Data collected were analyzed using descriptive statistics while hypothesis was tested using Chi-square statistics significant at 0.05. Findings of the study revealed that excessive workload, assaults and violence were the major hazards nurses were exposed to, while occupational illnesses including body pains, stress/psychosocial problems, and back pain were reported among the nurses. Nurses were found to exhibit good practice of prevention of occupational hazard, and there was a statistically significant relationship between years of work experience and practice of prevention of occupational hazard among Nurses in the Hospital. Prominent factors found associated with occupational hazard were; insufficient safety gadgets and equipment in the Hospital, long working hours, lack of adequate safety training, excessive workload, and inadequate staff strength in the Hospital. Based on these findings, it was recommended that government should embark on recruitment of more Nurses to reduce work load and enhance compliance to infection control practices in the Hospital.

Keywords: Occupational hazard, Prevalence, Factors, Prevention and Practice 


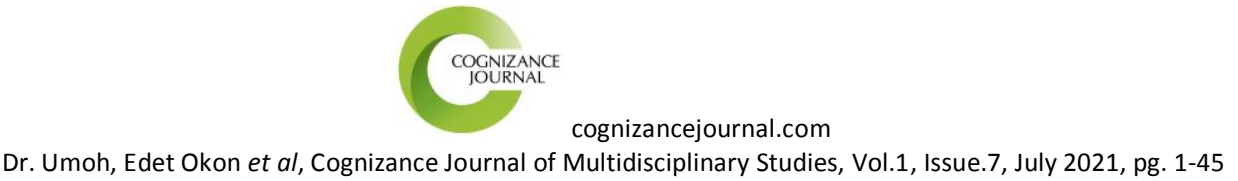

ISSN: 0976-7797

\section{Introduction}

Environment is full of hazard and risk to endanger human and animal life living around. When an individual is of age to make a living, his essential environment is where he makes an occupation which condition constitutes his hazard (Centre for Disease Control [CDC], 2016). Therefore occupational hazards are risks, danger or harm which a worker is exposed to at place of work (Awodele, Popoola, Ogbudu, Akinyede, Coker, \& Akintowa, 2014). Hazards are inherent property of an institution, situation, agent or source of energy which is potential of causing undesirable consequences while risk is the probability that may cause damage to life, health, and/or environment which occur from a hazard. In this regard, occupational hazards refer to workplace activities, components and environment that has the potential to cause/increase the risk of injury or ill health to a worker in the course of delivering duty (Ford \& Tetrick, 2011).

According to recent International Labor Organization (ILO) (2018) estimates, the global number of work-hazards does not seem to have changed significantly during the past 10 years. These are mainly driven by the globalization process and by rapid industrialization in relatively poor countries that are not capable of maintaining effective occupational safety and health systems. Therefore, it has been argued that the need to focus on health and safety are paramount as ever, given that "the traditional hazard and risk prevention and control tools are still effective but needed to be completed by strategies designed to address the consequences of a continuous adaptation to a rapidly changing world of work".

Traditionally, professionals working in a hospital are seen as people who are capable of keeping their health without help and hospitals and other health facilities are also considered to be safer 


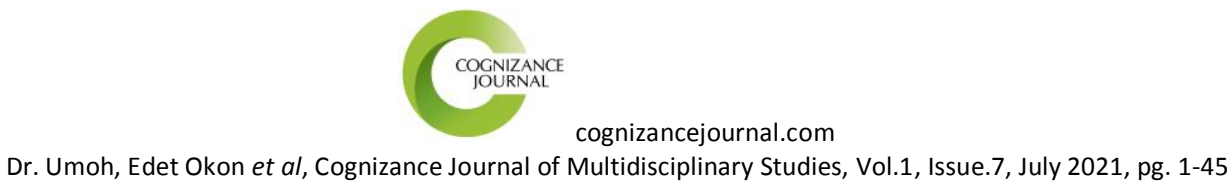

ISSN: 0976-7797

than other workplaces. As a result few resources are allocated to the occupational health of these hospital workers. However, the hospital environment presents healthcare employees with various occupational hazards, including exposure to infectious agents, needle stick and sharp injuries, musculoskeletal disorders (MSD), exposure to carcinogenic agents, latex allergies, violence and stress (Lugah, et al., 2010).

In view of the above, the World Health Organization (WHO) in 2007 endorsed the Global Plan of Action on Workers' Health, to be implemented from 2008-2017 to provide political framework for development of infrastructure, policies, technologies and partnerships for achieving basic level of occupational safety throughout the world (WHO, 2007). The Global Plan of Action addresses all aspects of employees' health, including prevention of workplace hazards, protection and promotion of safety practices at work, employment conditions and improving the response of health systems to employees' health. It, thus, links occupational health to public health (Bekele, Gebremariam, Kaso, \& Ahmed, 2015).

Given the nature of nursing working environment, responsibilities and duties, nurses are on the frontline of numerous occupational hazards such as biological/infectious disease, chemical risks, environmental/ mechanical risks, physical risks, and psychosocial risks (Senthil et al, 2014). According to Gallant-Roman (2018), nursing is one of the hazardous occupations, in which the risks are four times higher than those in other professions. The dangers that threaten nurses include biological risks emerged from the exposure to infectious agents, risks of chemical contacts, physical dangers, ergonomic hazards, attacks and beatings, and negative effects of psychosocial and organizational factors (Walton \& Rodgers, 2017).Hence, nurses are prone to 


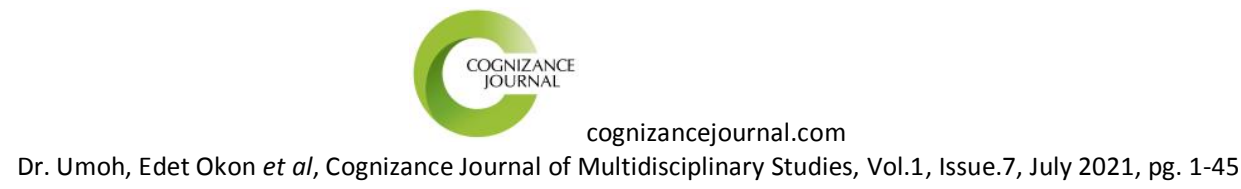

ISSN: 0976-7797

occupational hazards and injuries in the course of their day to day activities in the health care settings (Isara \& Ofili, 2012). However, the safety of nurses from workplace-induced injuries and illnesses is paramount to nurses themselves as well as to the patients they serve. The presence of healthy and well-rested nurses is critical to providing vigilant monitoring, empathic patient care, and vigorous advocacy.

In a psychiatry facility, the main cause of hazard among mental health nurses is the working environment, routine responsibilities, and duties which they are obliged to perform. These put them in the frontline of numerous occupational hazards which can be acute or long term. Some health outcome includes musculo-skeletal injuries/disorders, infections, changes in mental health, cardiovascular, metabolic and neoplastic diseases (Caruso, 2014). The author further posits other hazards like work stressors resulting from organization of their duty into shift duty, call duty and long hours. According to Irtyah, Lamia \& Ahlem (2017), shifting duties exert adverse effects by disturbing circadian rhythm, sleep, social and family life with consequential outcome like obesity; type two diabetes and cardiovascular disorders.

Because of its peculiar nature, it is of necessary and crucial to identify the hazards related to the psychiatric health facility and recognize the appropriate strategies to prevent their occurrence in a way that nurse health is not affected. Therefore, considering causes and types of occupational hazards in this health setting is of utmost necessity. Based on this backdrop, this study aimed to determine the prevalence of occupational hazards among mental health nurses in Federal Psychiatric Hospital, Calabar, Cross River State. 


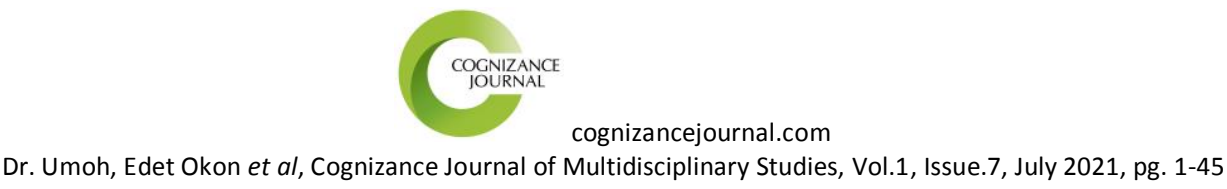

ISSN: 0976-7797

\section{Statement of Problem}

The burden caused by occupational hazard and illnesses on workers' health are enormous. According to the International Labour Organization, 4\% of the world's annual Gross Domestic Profit (GDP) is lost as a result of occupational hazards as employers are faced with loss of skilled staff, absenteeism, migration, early retirements and high insurance premiums due to exposure from occupational accidents and diseases (ILO, 2016). Bell et al (2013) further emphasized that about 100,000 people die from occupational illnesses, while an estimated 400,000 new cases of occupational diseases are diagnosed every year. However, evidence has shown that nursing is among the occupation with highest risk of exposure to high risk occupational hazards (Bell et al, 2013).

Over the last 30 years, healthcare facilities in Nigeria have significantly increased in magnitude; sophistication and diversity accompanied with challenges on ensuring and sustaining best practices and equipment required performing high risk clinical procedures (Oluwagbemi, 2017). Similarly, protecting the health and wellbeing of front line health workers especially the nurses in these facilities is difficult. Hence, while discharging their statutory obligations, nurses are exposed to hazards which significantly impair their health and quality of life, with multiple effects on their immediate and extended family members.

The predominant hazards nurses are exposed to include; blood-borne infections [Human Immunodeficiency Virus (HIV), Hepatitis B virus (HBV) and Hepatitis C virus (HCV)], back and neck pain, burn-out stress, allergic reactions to latex materials, spills from chemicals, exposure to radiation, assault from patients; among others (Amosun, Degun, Atulomah, 


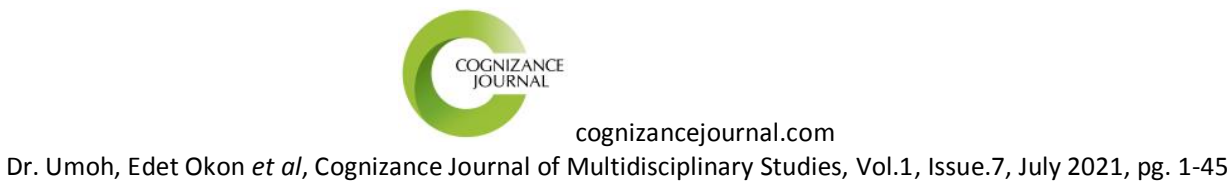

ISSN: 0976-7797

Olanrewaju \& Aderibigbe, 2017). Iyamuremye and Brysiewicz (2018) explored secondary traumatic stress in mental health nurses working in Kigali, Rwanda. The study indicated that majority of the nurses had a high T-score showing exposure to extremely high risks work place hazards. Another study on perceived disability and contributing risk factors to work-related low back pain amongst nurses in Rwanda, showed a Disability Index that demonstrated a mild to moderate disability due to work related low back pain among nurses used for the study (Ndagijimana, 2017).

In the study area, prevalence of hazard is enormous occurring in every shift and at any time of the shift extending from the least expected (calm) to aggressive (violent) patients. FNPH/NAR/Vol.1/2016 reveals nurses risk as falls, attack, assault and insult from fresh patients, challenge by patients who wants to escape, needle prick injury, noise from generators and danger from separating fighting patients. Nurses on night duty complained of leg pain, waist pain, backache and strained as a result of long tracking and working under cold weather. On return from one night duty, Nurse Okon presented his torned shirt by a female patient in his attempt to stop her from fighting the other.

According to Amosun et al (2017), the associated factors that lead to nurses' exposure to occupational illnesses and injuries include; negligence and carelessness, lack of adequate protective aids and equipment, inadequate number of staff, excessive workload, failure to observe basic safety and hygiene guidelines, and inadequate operational knowledge of modern healthcare equipment. These prompted the US Centre for Disease Control and Prevention (CDC) to develop standard precautions (SPs) for preventing occupational exposures and handling of 


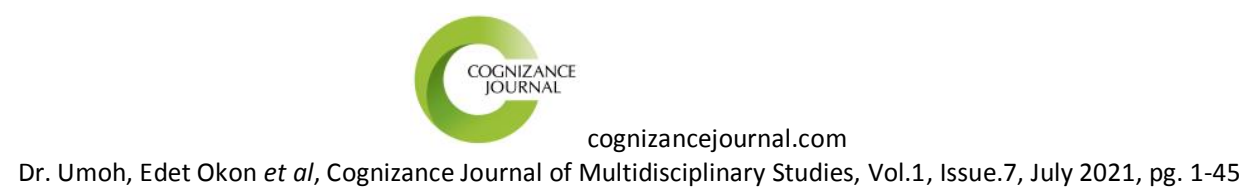

ISSN: 0976-7797

infectious materials in Healthcare facilities (Molinari, 2013). Adherence to the SP guidelines has been shown to be effective in curtailing occupational illnesses and injuries among healthcare workers including Nurses in healthcare facilities (Ayalu et al, 2017).

This study is however essential in providing information that could contribute to the occupational safety and health of nurses in Federal Neuropsychiatric Hospital, Calabar, by giving information on the prevalence rate of occupational health hazards among nurses in this mental health facility. It would further generate information necessary to mitigate strategies for policy adjustment and to analyze the effects of program on safety performances of nurses in Federal Neuropsychiatric Hospital, Calabar, Cross River State.

\section{Purpose of the study}

The general purpose of this study was to examine the prevalence of occupational hazard among mental health nurses in Federal Neuropsychiatric Hospital, Calabar, Cross River State.

Specifically, this study sought to:

1. Examine the prevalence rate of occupational hazards and illnesses among nurses in Federal Psychiatric Hospital, Calabar

2. Find out the factors associated with occupational hazards and illnesses among nurses in Federal Psychiatric Hospital, Calabar

3. Ascertain the level of practice of prevention of occupational hazards among nurses in Federal Psychiatric Hospital, Calabar 


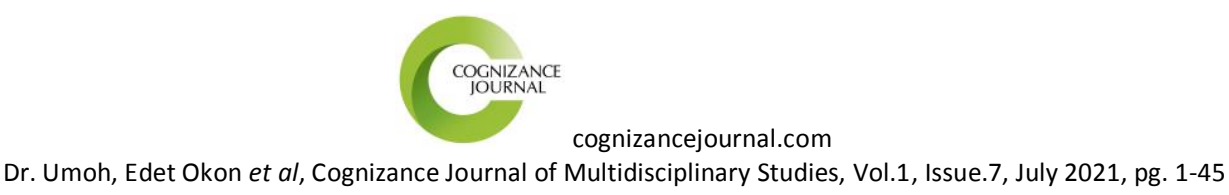

ISSN: 0976-7797

\section{Research questions}

1. What is the prevalence rate of occupational hazards and illness among nurses in Federal Psychiatric Hospital, Calabar?

2. What are the factors associated with occupational hazards and illness among nurses in Federal Psychiatric Hospital, Calabar?

3. What is the level of practice of prevention of occupational hazards among nurses in Federal Psychiatric Hospital, Calabar?

\section{Research hypothesis}

$\mathrm{H}_{0}$ : There is no significant relationship between years of experience and compliance with safety precautions among nurses in Federal Psychiatric Hospital, Calabar.

\section{Scope of the study}

This study is delimited to the prevalence of occupational hazard among nurses and the factors associated with occupational hazards. It also covers the safety practices adopted by nurses to prevent occurrence of occupational hazards. The study is restricted to mental health nurses working in Federal Neuropsychiatric Hospital, Calabar, Cross River State.

\section{Significance of the study}

Occupational hazard increases morbidity, mortality and medical cost. Adequate infection control practice is significant to reduce the incidence of occupational hazard and enhance quality health care delivery in healthcare institutions and reduce the length of patient stay in the hospital. 


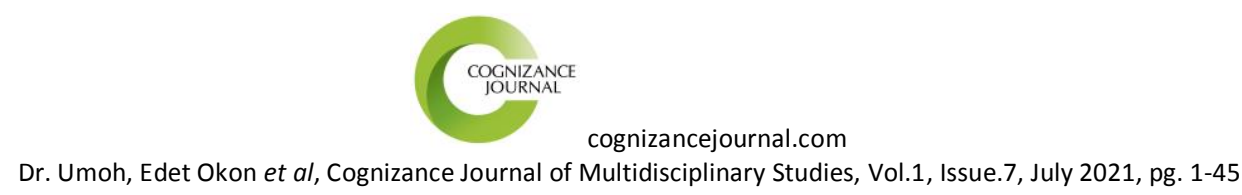

Findings from this study will equip nurses with knowledge of the associated factors to occupational hazard. This will improve their attitude towards practice of prevention of occupational hazard thereby reducing the incidence of occupational diseases and death among the nurses.

The study recommendations will be of benefit as it will draw the attention of the hospital management in the provision of devices and equipment necessary to protect the nurses, and also ensure that the work environment is safe thereby reducing the level of nurses' exposure to hazards and increasing productivity.

Result from this study will form a yard stick in training health care personnel to uphold precaution in preventing occupational hazards Furthermore the study will assist and encourage government and relevant agencies to adopt occupational health programs and formulate policies and strategies that will improve working condition for HCWs including the nurses.

This study will be of immense benefit to students and researcher as it will serve as a springboard for further research.

\section{Limitations of the study}

The researcher met the following hitches that constrained the smooth conduct of the study:

1. Hospital policy over release of information

2. Poor documentation of incidence by nurses

3. Poor storage system to preserve information

4. Lack of interest and returns of response by participating nurses 


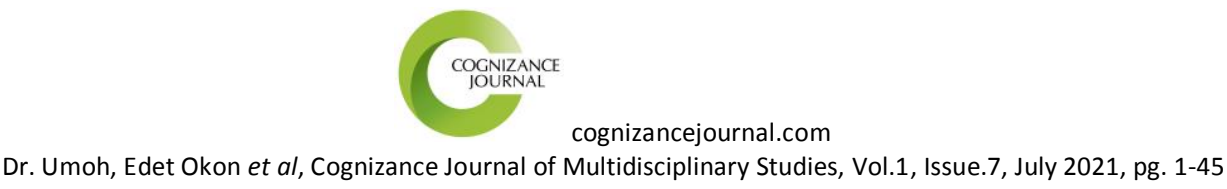

5. Effect of Endsars protest in the institution

6. Lack of fund to foster the project

Despite the numerous hitches, with tact and painstaking I was able to wriggle out of the limitations and complete the study.

\section{METHODOLOGY}

\section{Research design}

This study adopts a cross-sectional descriptive survey design. The survey design particularly aimed at describing the nature of a situation that exists as at the time of the study. It gives a precise representation of the characteristic of persons, phenomena, situation, population or groups and/or the rate with which certain occurrence takes place. According to Ndiyo (2010), the survey design is a study design that involves selecting and studying of samples derived from populations of interest to ascertain the relative occurrence, distribution and interrelations of variables of sociological and psychological relevance. Therefore, the design is adopted to facilitate the investigation on the prevalence of occupational hazard among mental health nurses in Federal Neuropsychiatric Hospital, Calabar, Cross River State.

\section{Population of study}

The population of this study consists of mental health nurses in any of 10 wards and/units in Federal Neuropsychiatric Hospital, Calabar, Cross River State. Based on a recent Administrative Report of the Hospital, the population of nurses in the Hospital stands at 111 which constitute the target population of the present study. 


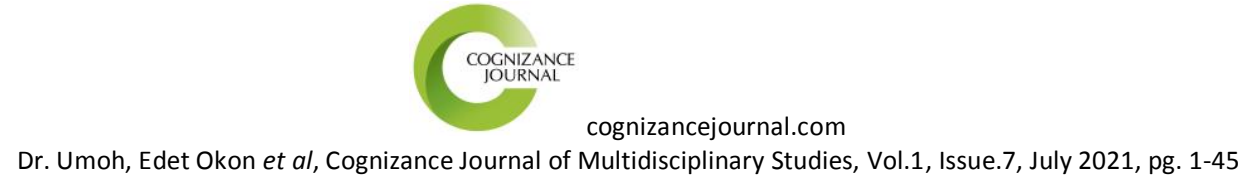

ISSN: 0976-7797

\section{Sample and sampling technique}

The sample size of this study is made up of 87 mental health nurses in Federal Neuro-psychiatric Hospital, Calabar. This sample size was obtained using Taro Yemen formula for sample size determination. This formula is used when the target population of the study is known such as in the case of this study. The formula is as stated below:

$$
\mathrm{n} \quad=\frac{\mathrm{N}}{1+\mathrm{N}(\mathrm{e})^{2}}
$$

Where $\quad \mathrm{n}=$ sample size

$$
\begin{aligned}
& \mathrm{N}=\text { population size }=111 \\
& \mathrm{e}=\text { level of precision }=\quad 0.05 \\
& \mathrm{n} \quad=\frac{111}{1+111(0.05)^{2}} \\
& =86.9=87 \text { approx }
\end{aligned}
$$

Hence, the sample size for this study is 87 .

The sampling technique adopted for the study was the stratified random sampling. Each Ward/unit within the Hospital where nurses render their services was referred to as a stratum of the study population. The hospital consists of a total of 10 Wards/Units. To select nurses from each ward or unit a proportionate sampling technique was used. The sampling distribution for this study is presented in the table below. 
cognizancejournal.com

Dr. Umoh, Edet Okon et al, Cognizance Journal of Multidisciplinary Studies, Vol.1, Issue.7, July 2021, pg. 1-45

ISSN: 0976-7797

\section{Sampling distribution}

\begin{tabular}{cccc}
\hline S/No. & Wards/Unit & Nurse population & Sample size \\
\hline 1. & Ward 1 & 15 & 12 \\
2. & Ward 2 & 14 & 11 \\
3. & Ward 3 & 14 & 11 \\
4. & Ward 4 & 14 & 11 \\
5. & Ward 5 & 13 & 10 \\
6. & Ward 6 & 10 & 8 \\
7. & Ward 7 & 12 & 10 \\
8. & OPE & 13 & 10 \\
9. & OPC & 3 & 2 \\
10. & Staff Clinic & 3 & $\mathbf{8 7}$ \\
\hline & Total & $\mathbf{1 1 1}$ & 2 \\
\hline
\end{tabular}

To select the nurses from the respective Wards/Units, a random sampling technique was employed by the researcher. 


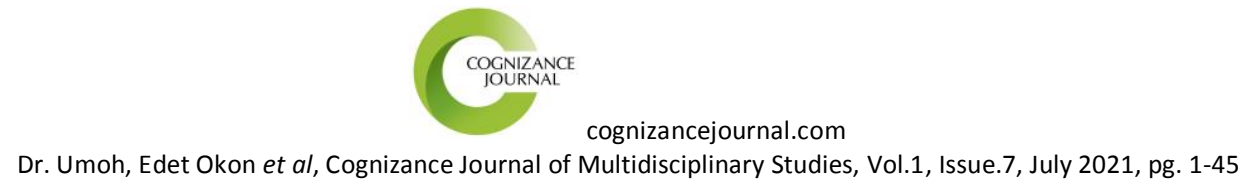

ISSN: 0976-7797

\section{Instrument for data collection}

A structured questionnaire was the instrument for gathering data for the study. The questionnaire was structured by the researcher based on the research questions. It comprised of four (4) sections, labeled A to D.

Section A requested for demographic data of the respondents. Section B comprised of closed ended questions which sought to assess the prevalence of occupational hazard among the nurses. Section C and D comprised of items structured to determine the factors associated with occupational hazards and the safety practices adopted by nurses to prevent the occurrence of occupational hazards. Items in section C and D were structured using the five (5) point Likert type scale with the following keys: Strongly Agree (SA), Agree (A), Disagree (D), Strongly Disagree (SD) and Undecided (U). Accordingly scores were awarded as follows:

For all positive questions

SA $\quad-\quad 4$ points

A $\quad-\quad 3$ points

D $\quad-\quad 2$ points

SD $\quad-\quad 1$ point

U $\quad-\quad 0$ point

For all negative questions

SA $\quad-\quad 1$ point

A $\quad-\quad 2$ points

D $\quad-\quad 3$ points 


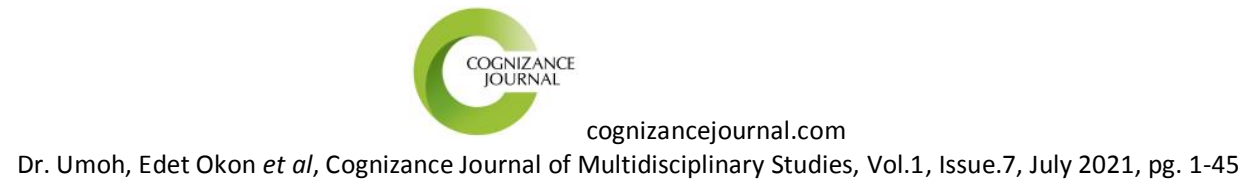

$\mathrm{SD} \quad-\quad 4$ points

U $\quad-\quad 0$ point

\section{Validity of instrument}

Validity of a research instrument refers to the extent to which the instrument measures what it is designed to measure. In this study, face validity was established. Face validity refers to the outward appearance of the questionnaire. It took care of the relevant content on which the questionnaire was based. The questionnaire was presented to the supervisor; and the supervisor after making relevant modification of items on the instruments certified that, the instrument could adequately measure the variables under study.

\section{Reliability of instrument}

To ascertain the reliability of the instrument, a test-retest method was adopted using similar instrument to review 10 clinical nurses working in the Psychiatric Unit of University of Calabar Teaching Hospital, Calabar. After an interval of two weeks same participants were given another questionnaire. Using Spearman Rank Order Correlation analysis, scores in both tests were ranked and correlated. The reliability coefficients obtained ranged from 0.918 to 0.965 as presented in the table below. This shows that the instrument is reliable, hence, could measure the variables under investigation. 
Estimation of Reliability Coefficient through test-retest technique

\begin{tabular}{|c|c|c|c|c|c|c|}
\hline S/No & Variables & $\mathbf{N}$ & $\begin{array}{c}\text { Test } \\
\text { positions }\end{array}$ & $\overline{\mathbf{X}}$ & SD & $\mathbf{r}_{\text {-cal }}$ \\
\hline 1. & Prevalence of occupational hazard & 10 & $\begin{array}{l}1^{\mathrm{st}} \text { test } \\
2^{\text {nd }} \text { test }\end{array}$ & $\begin{array}{l}23.63 \\
23.59\end{array}$ & $\begin{array}{l}4.91 \\
5.06\end{array}$ & 0.929 \\
\hline 2. & $\begin{array}{l}\text { Factors associated with } \\
\text { occupational hazard }\end{array}$ & 10 & $\begin{array}{l}1^{\text {st }} \text { test } \\
2^{\text {nd }} \text { test }\end{array}$ & $\begin{array}{l}26.37 \\
26.12\end{array}$ & $\begin{array}{l}3.86 \\
4.04\end{array}$ & 0.965 \\
\hline 3. & $\begin{array}{l}\text { Practice of prevention of } \\
\text { occupational hazard }\end{array}$ & 10 & $\begin{array}{l}1^{\text {st }} \text { test } \\
2^{\text {nd }} \text { test }\end{array}$ & $\begin{array}{l}17.87 \\
17.22\end{array}$ & $\begin{array}{l}3.15 \\
3.44\end{array}$ & 0.918 \\
\hline
\end{tabular}

Source: Questionnaire

\section{Procedure for data collection}

The researcher adopted a face-to-face administration of the questionnaire. With the aid of a student nurse, the researcher distributed the questionnaire to nurses selected from various wards/clinics in the hospital. The purpose of the study was clearly stated to the respondents and confidentiality of information assured. However, repeated visits were made to cover those respondents in morning, evening and night shifts; and on-the-spot collection of responded questionnaire was maintained. A total of eighty-seven (87) questionnaires were distributed, same were properly filled and returned to the researcher giving a $100 \%$ response rate. 


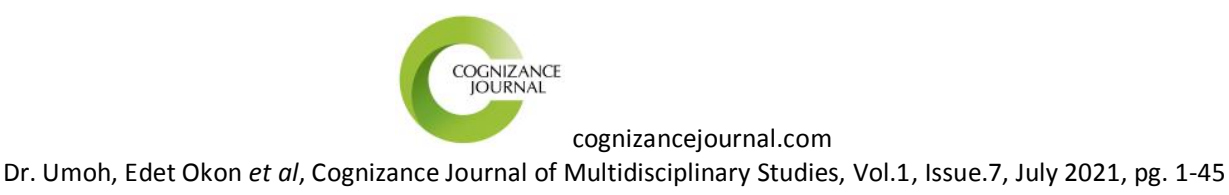

ISSN: 0976-7797

\section{Method of data analysis}

Data collected from the respondents were grouped, analyzed and interpreted using frequency, simple percentages, mean, and standard deviations. The research hypothesis was tested using chi-square statistical tool (at 0.05 level of significance).

\section{Ethical consideration}

The researcher obtained a letter of introduction from the Head of Nursing Department of National Open University, Calabar Study Centre and submitted to the Medical Director and Ethical Committee of the Hospital through the Head of Nursing Services to obtain permission for the study. The respondents were informed of the study procedure and that choice of participation is voluntary. The privacy of the respondents was maintained throughout the study. Also, authors of books and other materials used in this study were properly cited and referenced according to the required standard.

RESULTS, ANALYSIS AND DISCUSSION

Presentation and analysis of demographic data

Distribution of respondents by Gender $(n=87)$

\begin{tabular}{|c|c|c|c|}
\hline S/No & Gender & Frequency & Percentage $(\%)$ \\
\hline 1. & Male & 37 & 42.5 \\
\hline 2. & Female & 50 & 57.5 \\
\hline & Total & 87 & 100 \\
\hline
\end{tabular}

Source: Fieldwork, 2021. 
Table 4.1 above presents the respondents by gender. The Table reveals that 37 (42.5\%) out of the 87 respondents were male, while the remaining proportion $50(57.5 \%)$ were female.

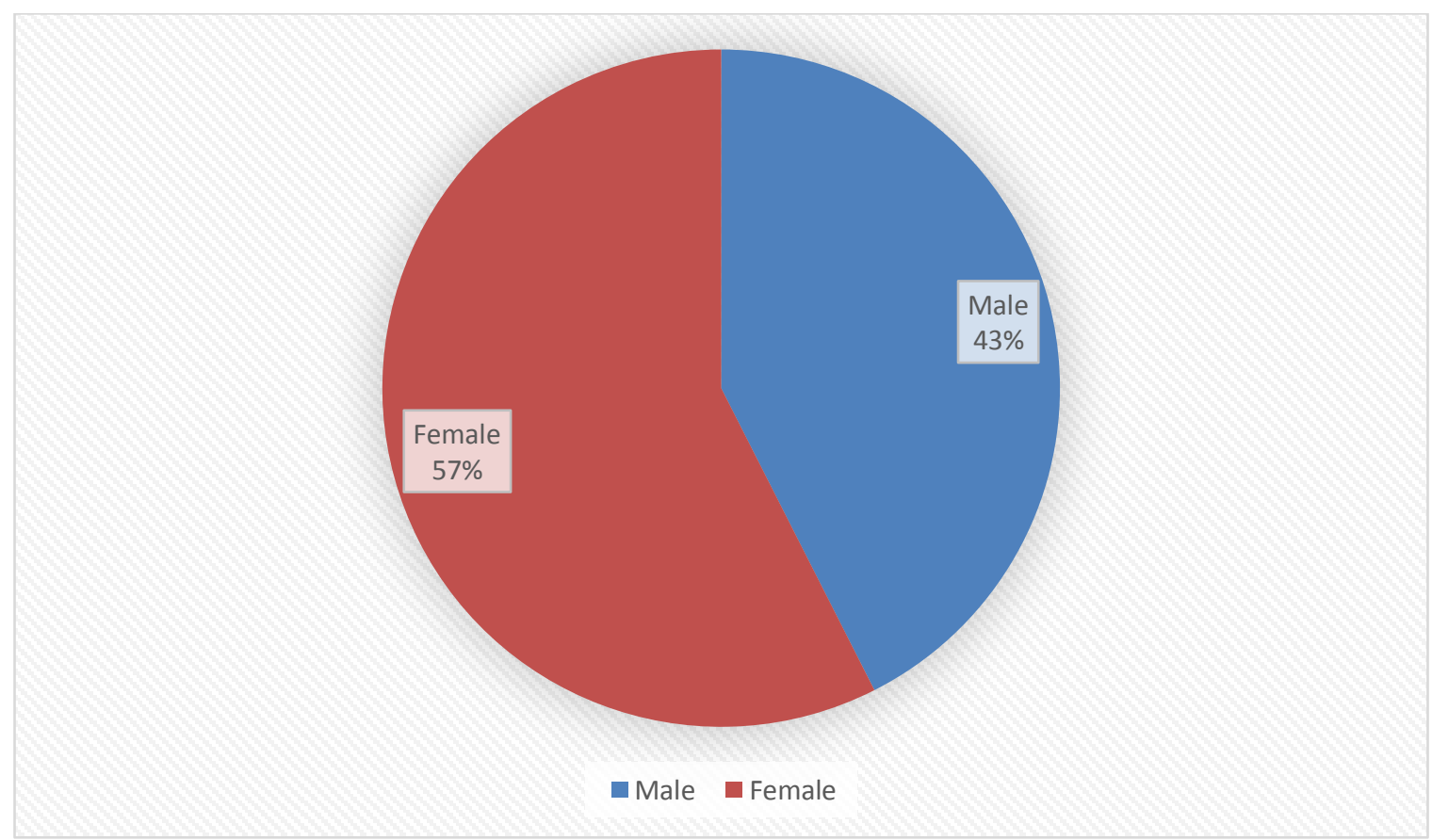

Pie chart showing the respondents by gender

Distribution of respondents by age $(n=87)$

\begin{tabular}{cccc}
\hline S/No & Age (years) & Frequency & Percentage (\%) \\
\hline 1. & $\leq 20$ & 3 & 3.5 \\
2. & $21-30$ & 14 & 16.1 \\
3. & $31-40$ & 31 & 35.6 \\
4. & $41-50$ & 25 & 28.7 \\
5. & Above 50 & 14 & 16.1 \\
& Total & $\mathbf{8 7}$ & $\mathbf{1 0 0}$
\end{tabular}

Source: Fieldwork, 2021. 
cognizancejournal.com

Dr. Umoh, Edet Okon et al, Cognizance Journal of Multidisciplinary Studies, Vol.1, Issue.7, July 2021, pg. 1-45

ISSN: 0976-7797

The table above shows that $3(3.5 \%)$ of the 87 respondents were less but not more than 20 years of age, while $14(16.1 \%)$ were between 21-30 years and above 50 year respectively, $31(35.6 \%)$ were between 31-40 years, and 25 (28.7\%) were between 41-50 years of age.

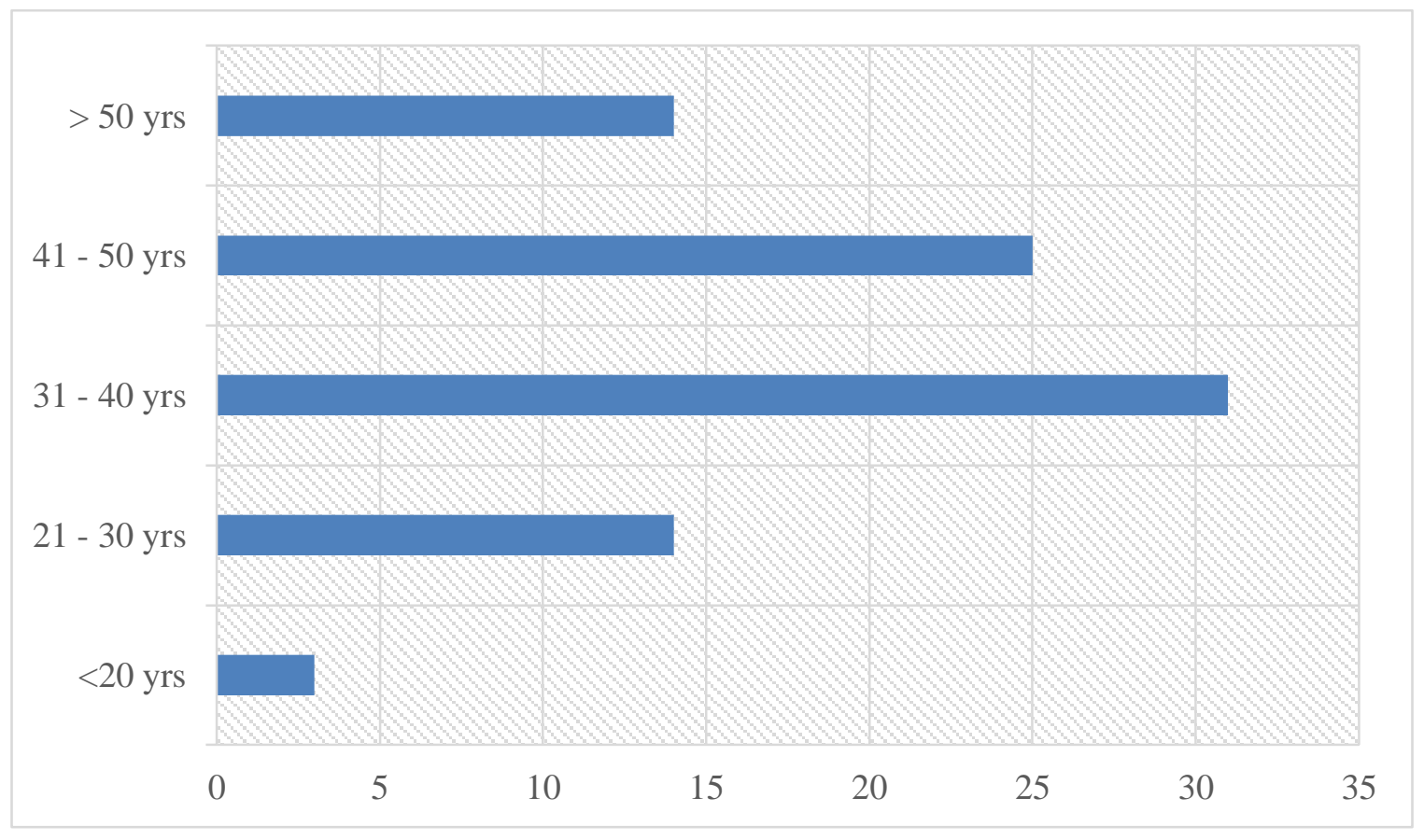

Bar chart showing the respondents by age

Distribution of respondents by marital status $(n=87)$

\begin{tabular}{clcc}
\hline S/No & \multicolumn{1}{c}{ Marital status } & Frequency & Percentage (\%) \\
\hline 1. & Single & 24 & 27.6 \\
2. & Married & 38 & 43.7 \\
3. & Separated & 6 & 6.9 \\
4. & Divorced & 8 & 9.2 \\
5. & Widow & 11 & 12.6 \\
& Total & $\mathbf{8 7}$ & $\mathbf{1 0 0}$ \\
\hline
\end{tabular}

Source: Fieldwork, 2021. 
cognizancejournal.com

Dr. Umoh, Edet Okon et al, Cognizance Journal of Multidisciplinary Studies, Vol.1, Issue.7, July 2021, pg. 1-45

ISSN: 0976-7797

The table above shows that among the 87 respondents $24(27.6 \%)$ were single, while $38(43.7 \%)$ were married, $6(6.9 \%)$ were separated, 8 (9.2\%) were divorced, and $11(12.6 \%)$ were widow and/or widowers.

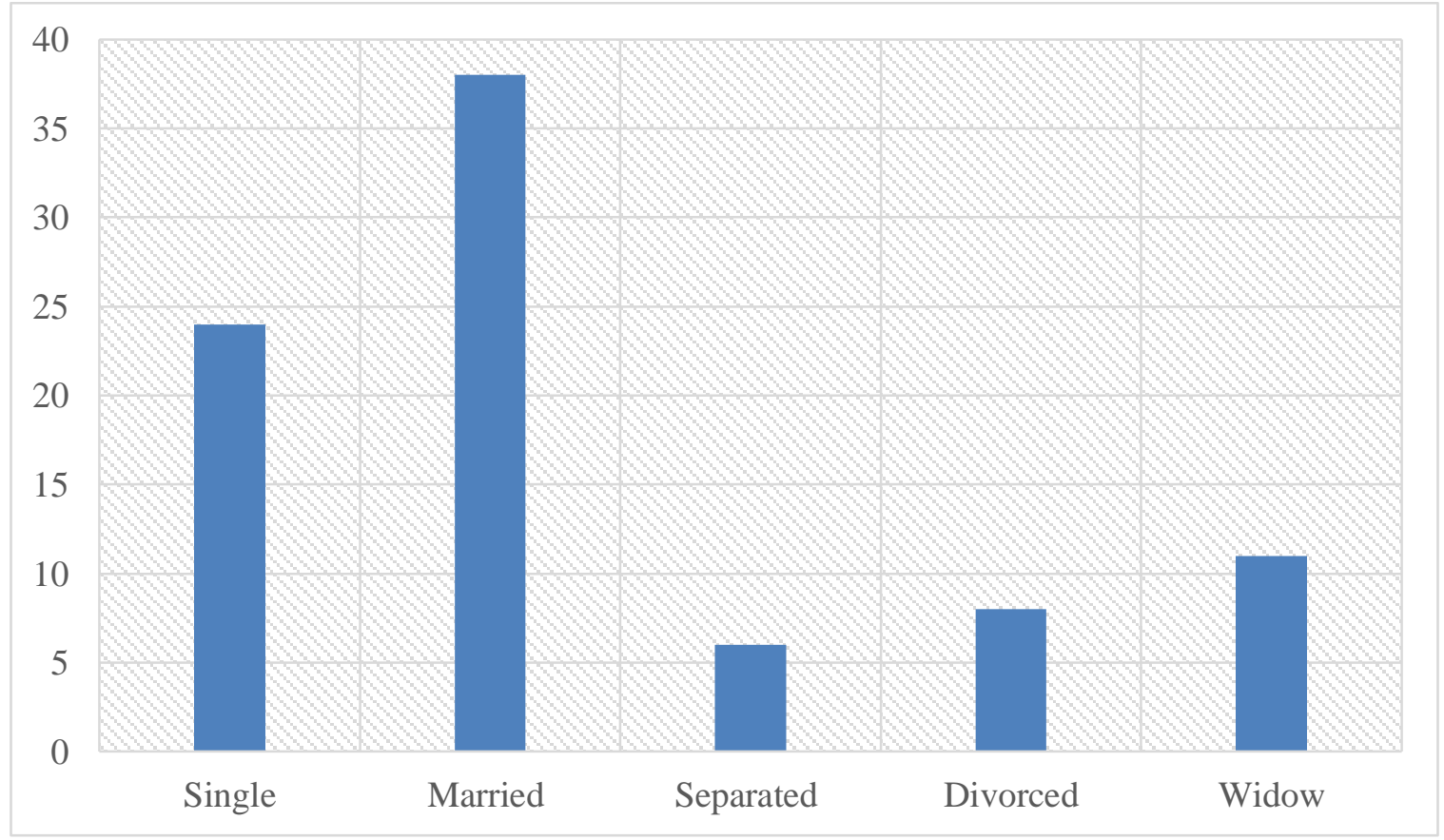

Bar chart showing the respondents by marital status

Distribution of respondents by religion $(n=87)$

\begin{tabular}{rlcc}
\hline S/No & Religion & Frequency & Percentage (\%) \\
\hline 1. & Muslim & 3 & 3.4 \\
2. & Christianity & 84 & 96.6 \\
3. & Traditional & - & 0.0 \\
& Total & $\mathbf{8 7}$ & $\mathbf{1 0 0}$ \\
\hline
\end{tabular}

Source: Fieldwork, 2021. 
cognizancejournal.com

Dr. Umoh, Edet Okon et al, Cognizance Journal of Multidisciplinary Studies, Vol.1, Issue.7, July 2021, pg. 1-45

ISSN: 0976-7797

The table presents the respondents by religion. According to the table, $3(3.4 \%)$ out of the 87 respondents were Muslim, while 84 (96.6\%) were Christians, and none of the respondents was a traditional worshiper.

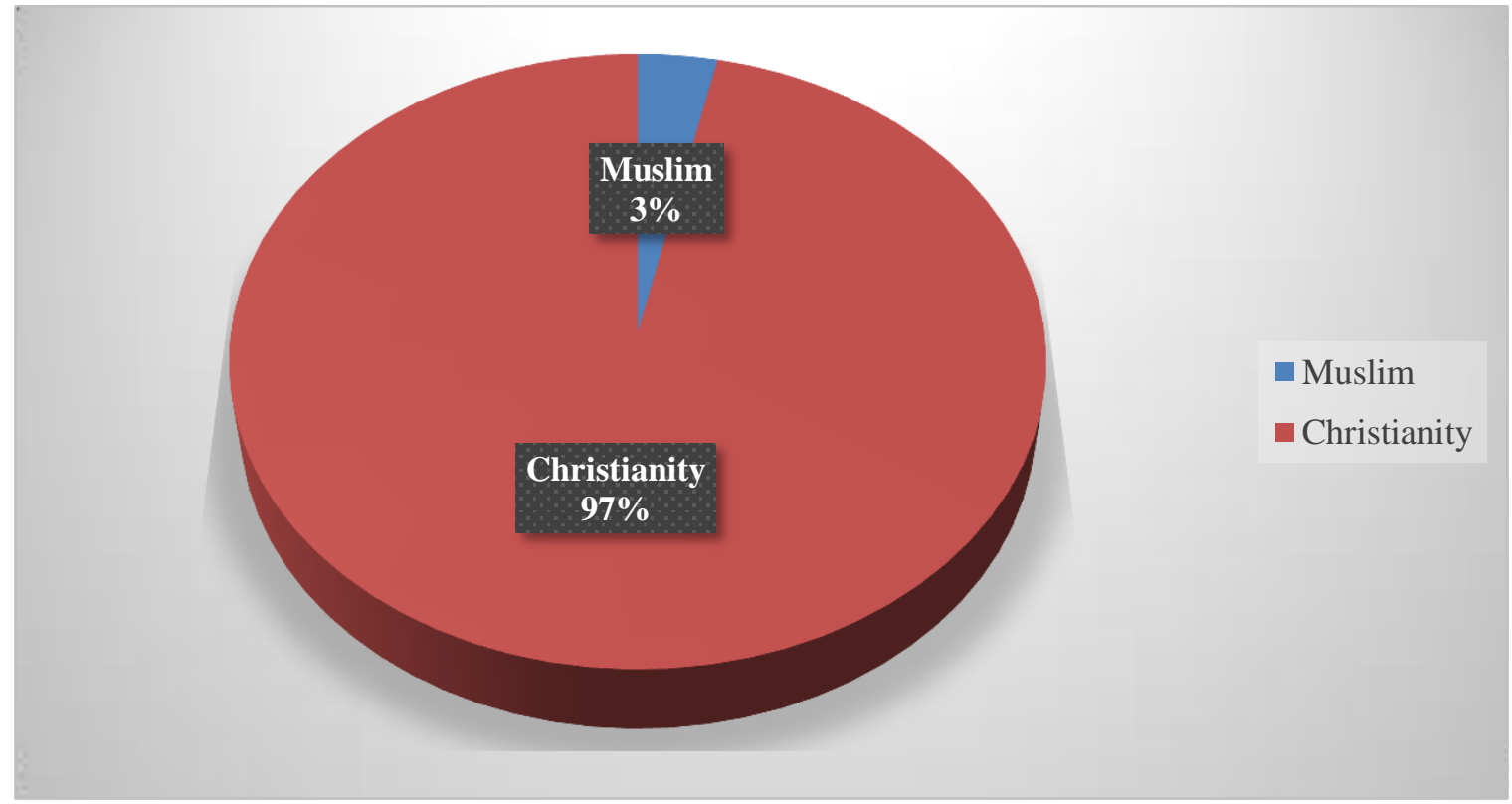

3-D pie chart showing the respondents by religion

Distribution of respondents by Ranks $(n=87)$

\begin{tabular}{|c|c|c|c|}
\hline S/No & Rank & Frequency & Percentage $(\%)$ \\
\hline 1. & NO II & 22 & 25.3 \\
\hline 2. & NO I & 18 & 20.7 \\
\hline 3. & SNO & 15 & 17.2 \\
\hline 4. & PNO & 15 & 17.2 \\
\hline 5. & $\mathrm{ACNO}$ & 9 & 10.4 \\
\hline 6. & $\mathrm{CNO}$ & 8 & 9.2 \\
\hline & Total & 87 & 100 \\
\hline
\end{tabular}

Source: Fieldwork, 2021. 
cognizancejournal.com

Dr. Umoh, Edet Okon et al, Cognizance Journal of Multidisciplinary Studies, Vol.1, Issue.7, July 2021, pg. 1-45

The table above shows that $22(25.3 \%)$ out of the 87 respondents were Nursing Officer II, 18 (20.7\%) were Nursing Officer I, while 15 (17.2\%) were Senior Nursing Officers and Principal Nursing Officers respectively, 9 (10.4\%) were Acting Chief Nursing Officers, and 8 (9.2\%) were Chief Nursing Officers.

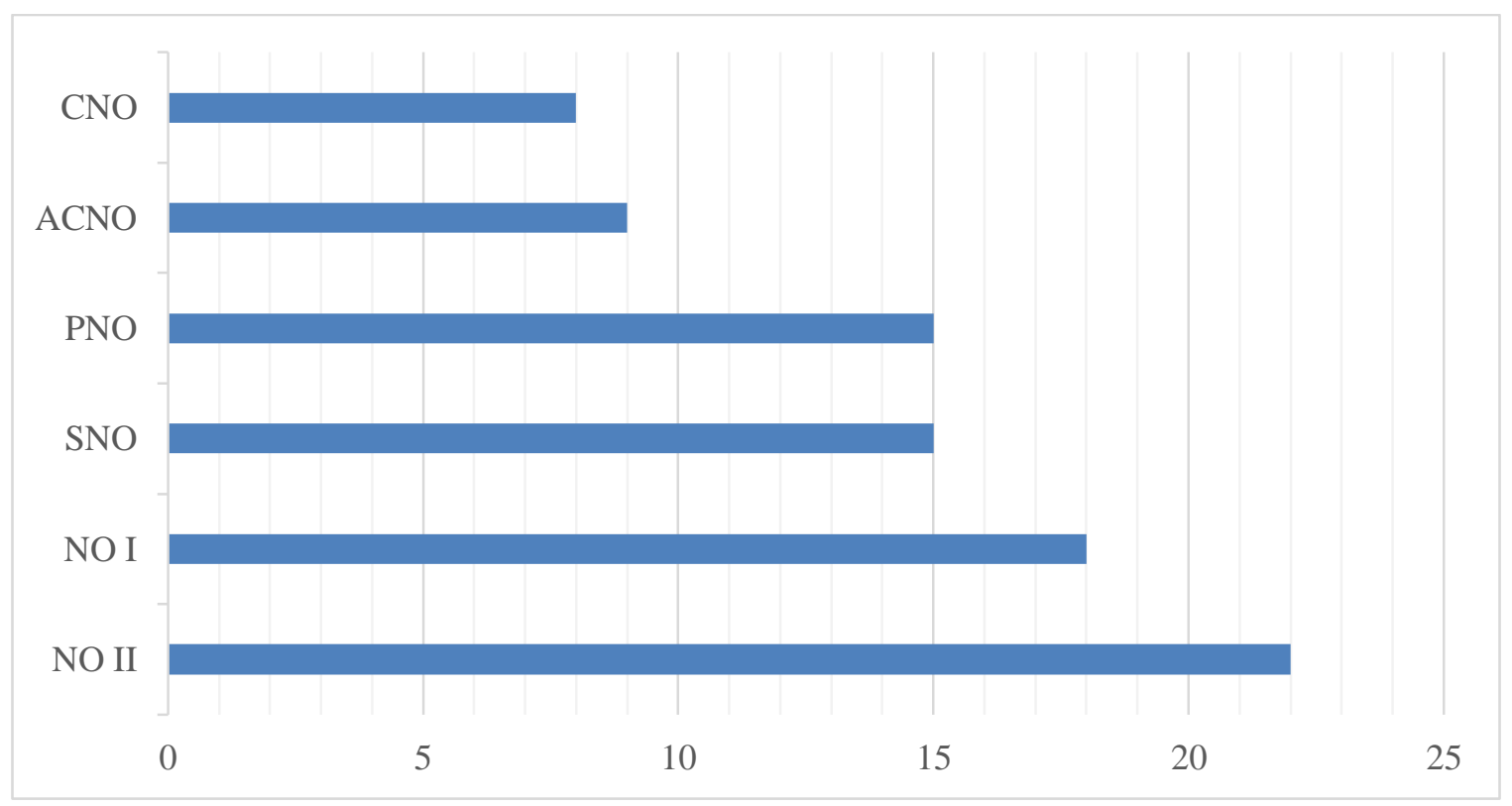

Bar chart showing the respondents by Ranks

Distribution of respondents by years of experience $(n=87)$

\begin{tabular}{cccc}
\hline S/No & Years of experience & Frequency & Percentage (\%) \\
\hline 1. & $\leq 10$ years & 32 & 36.8 \\
2. & $11-20$ years & 27 & 31.0 \\
3. & $21-30$ years & 16 & 18.4 \\
4. & Above 30 years & 12 & 13.8 \\
& Total & $\mathbf{8 7}$ & $\mathbf{1 0 0}$ \\
\hline
\end{tabular}

Source: Fieldwork, 2021. 
The table above shows that out of the 87 respondents, 32 (36.8\%) had worked in the hospital for less but not more than 10 years, while $27(31.0 \%)$ had working experience between 11-20 years, $16(18.4 \%)$ had work experience of 21 - 30 years, and $12(13.8 \%)$ had worked in the hospital for over 30 years.

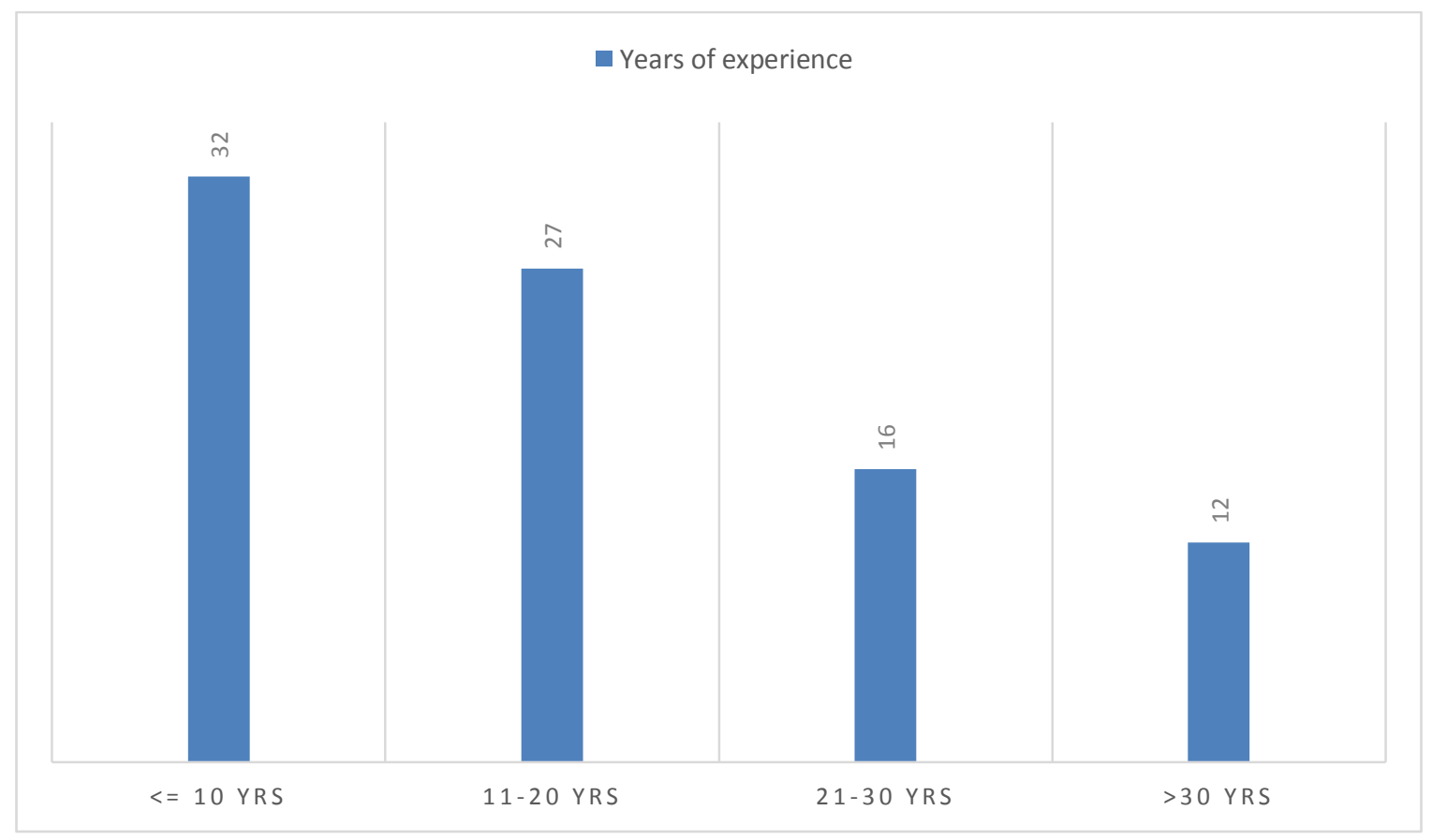

Bar chart showing the respondents by years of experience

\section{Answering of research questions}

Research question 1: What is the prevalence rate of occupational hazard and illnesses among mental health nurses in Federal Psychiatric Hospital, Calabar?

To answer this question items under section B of the research questionnaire were analyzed and results presented in the table below. 
Prevalence of occupational hazard $(n=87)$

Options

S/No. Occupational hazards

1. Slips/falls

2. Working accidents

3. Insect bites

4. Animal bites

5. Violence

6. Assaults

7. Injury with blood borne pathogens

8. Contagious waste hazards

9. Chemical splash

10. Burns from fire outbreak
Yes

Yes
19
$(21.8 \%)$
25

0

0
$(0.0 \%)$$$
49
$$

66

10

$(11.5 \%)$

0

$(0.0 \%)$

0
Total

87

(100\%)

87

(100\%)

87

$(100 \%)$

87

(100\%)

87

(100\%)

87

$(100 \%)$

87

$(100 \%)$

87

(100\%)

87

(100\%)

87 


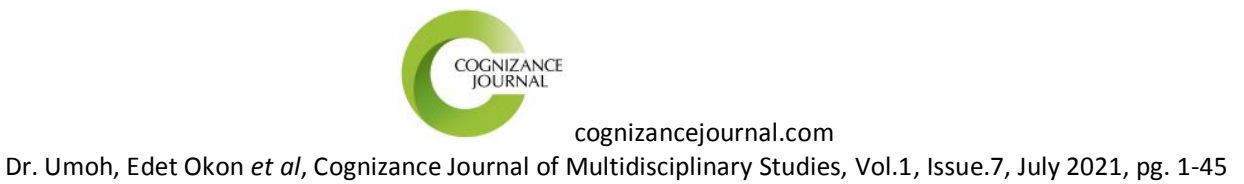

ISSN: 0976-7797

\begin{tabular}{|c|c|c|c|c|}
\hline & & $(0.0 \%)$ & $(100 \%)$ & $(100 \%)$ \\
\hline \multirow[t]{2}{*}{11.} & Confined space & 0 & 87 & 87 \\
\hline & & $(0.0 \%)$ & $(100 \%)$ & $(100 \%)$ \\
\hline \multirow[t]{2}{*}{12.} & Electric Shock & 5 & 82 & 87 \\
\hline & & $(5.8 \%)$ & $(94.2 \%)$ & $(100 \%)$ \\
\hline \multirow[t]{2}{*}{13.} & Strained relationship with patients & 27 & & \\
\hline & & $(31.0 \%)$ & $(69.0 \%)$ & $(100 \%)$ \\
\hline \multirow[t]{2}{*}{14.} & Work overload & 69 & 18 & 87 \\
\hline & & $(79.3 \%)$ & $(20.7 \%)$ & $(100 \%)$ \\
\hline
\end{tabular}

Source: Fieldwork, 2021.

The table above presents the prevalence of occupational hazard among the respondents. According to the table, $19(21.8 \%)$ have had slips/falls while carrying out their responsibilities in the Hospital, while 68 (78.2\%) have not. 25 (28.7\%) have had accidents while working, and 62 (71.3\%) have not. $41(47.1 \%)$ have been bitten by insects in the Hospital, while 46 (52.9\%) said they do not have such experience. None of the respondents have been bitten by an animal; 49 $(56.3 \%)$ have been exposed to work place violence; $66(75.9 \%)$ have been assaulted; while only $3(3.5 \%)$ have had injury with blood borne pathogens; and $10(11.5 \%)$ have been exposed to contagious waste hazard. Similarly, the Table shows that among the 87 respondents, none of them have been exposed to chemical splash, burns from fire outbreak, confined space, respectively. $5(5.8 \%)$ have had electric shock; while $27(31.0 \%)$ have experienced strained relationship with patients and staffs respectively; and $69(79.3 \%)$ have experienced excessive 
workload in the Hospital. Among these hazards, the most significant was workload, closely followed by assaults and violence respectively.

Prevalence of occupational illnesses $(n=87)$

Options

S/No. Occupational illnesses

1. Back pain

Yes

No

Total

52

35

87

2. Neck pain

$(40.2 \%)$

$(100 \%)$

29

58

87

$(66.7 \%)$

(100\%)

3. Body pain

4. Sharp objects injuries/cuts

5. Sprain

$(100 \%)$

87

(100\%)

6. Skin problems

(41.4\%)

$(58.6 \%)$

87

13

(100\%)

7. Varicosis (lower extremity)

0
$(0.0 \%)$

8. Psychological problem

\begin{tabular}{c|c|c}
9 & 78 & 87 \\
$(10.3 \%)$ & $(89.7 \%)$ & $(100 \%)$
\end{tabular}




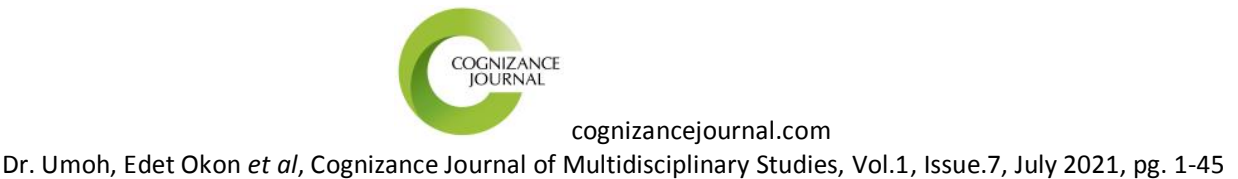

ISSN: 0976-7797

9. Blood borne infection

10. Stress/psychosocial problems

\begin{tabular}{c|c|c}
3 & 84 & 87 \\
$(3.5 \%)$ & $(96.5 \%)$ & $(100 \%)$ \\
68 & 19 & 87 \\
$(78.2 \%)$ & $(21.8 \%)$ & $(100 \%)$ \\
11 & 76 & 87 \\
$(12.6 \%)$ & $(87.4 \%)$ & $(100 \%)$ \\
24 & 63 & 87 \\
$(27.6 \%)$ & $(72.4 \%)$ & $(100 \%)$
\end{tabular}

Source: Fieldwork, 2021.

11. High blood pressure

12. Others

The table above shows that among the 87 respondents used for the study, 52 (59.8\%) have had back pains as a result of exposure to hazards in the Hospital. Similarly, 29 (33.3\%) have had neck pains, $71(81.6 \%)$ have had body pains, $42(48.3 \%)$ have had sharp object injuries/cuts, 36 (41.1\%) have experience sprain, 13 (14.9\%) have had skin problems, none of had varicosis, while $3(3.5 \%)$ have had blood borne infection, 68 (78.2\%) have been exposed to stress and/or psychosocial problems, $11(12.6 \%)$ have had high blood pressure, and 24 (27.6\%) have experienced other forms of illnesses due to their exposure to hazards in the Hospital.

\section{Research question 2: What are the factors associated with occupational hazards and illness among nurses in Federal Psychiatric Hospital, Calabar?}

To answer this question, items under section $\mathrm{C}$ of the questionnaire were analyzed and results presented in the table below. 
Factors associated with occupational hazards and illnesses among the respondents $(n=87)$

S/No. Items

Options

9. Poor occupational health practices by nurses

SA

10. Insufficient safety gadgets and equipment in the Hospital.

11. Long working hours.

12. Lack of adequate safety training.

13. Lack of knowledge/awareness regarding safety practices.

14. Excessive workload

15. Inadequate staff strength

\begin{tabular}{c|c}
$(11.5)$ & $(18.4)$ \\
40 & 33 \\
$(46.0)$ & $(37.9)$ \\
34 & 31 \\
$(39.1)$ & $(35.6)$
\end{tabular}

Source: Fieldwork, 2021. (Note: Nos in parenthesis are \%)

32

10

10

\begin{tabular}{c|c|c|c|c}
$\mathrm{A}$ & $\mathrm{U}$ & $\mathrm{D}$ & $\mathrm{SD}$ & Total \\
12 & 19 & 28 & 21 & 87 \\
$(13.8)$ & $(21.8)$ & $(32.2)$ & $(24.1)$ & $(100)$ \\
25 & 10 & 9 & 7 & 87 \\
$(28.7)$ & $(11.5)$ & $(10.3)$ & $(8.1)$ & $(100)$ \\
29 & 8 & 15 & 10 & 87 \\
$(33.3)$ & $(9.2)$ & $(17.2)$ & $(11.5)$ & $(100)$ \\
22 & 13 & 16 & 4 & 87 \\
$(25.3)$ & $(14.9)$ & $(18.4)$ & $(4.6)$ & $(100)$ \\
16 & 3 & 37 & 21 & 87 \\
$(18.4)$ & $(3.5)$ & $(42.5)$ & $(24.1)$ & $(100)$ \\
33 & 5 & 1 & 8 & 87 \\
$(37.9)$ & $(5.8)$ & $(1.1)$ & $(9.2)$ & $(100)$ \\
31 & 12 & 9 & 1 & 87 \\
$(35.6)$ & $(13.8)$ & $(10.3)$ & $(1.1)$ & $(100)$ \\
& & & &
\end{tabular}

among the respondents $(n=87)$ 


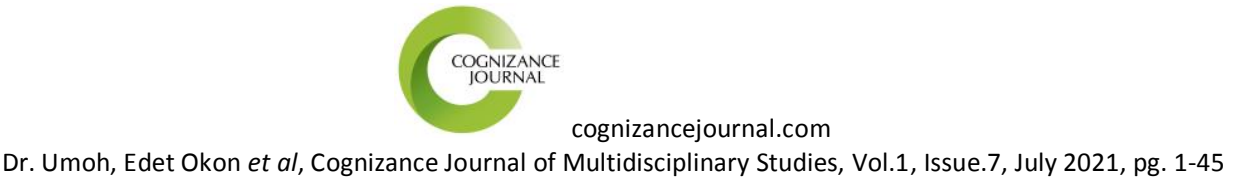

ISSN: 0976-7797

The table above presents the factors associated with occupational hazards and illnesses among the respondents. According to the table, $7(8.1 \%)$ out of the 87 respondents strongly agreed that poor occupational health practice by nurses in the Hospital results in exposure hazards, while 12 (13.8\%) agreed on this item, 19 (21.8\%) were undecided, $28(32.2 \%)$ disagreed, and $21(24.1 \%)$ strongly disagreed. $36(41.4 \%)$ respondents strongly agreed that insufficient safety gadgets and equipment is a reason why nurses are exposed to hazards in the Hospital, 25 (28.7\%) agreed, while $10(11.5 \%)$ were undecided, $9(10.3 \%)$ disagreed, and $7(8.1 \%)$ strongly disagreed. 25 (28.7\%) respondents strongly agreed that long working hours results in hazards in the Hospital, $29(33.3 \%)$ agreed, $8(9.2 \%)$ were undecided, while 15 (17.2\%) disagreed, and $10(11.5 \%)$ strongly disagreed. $32(36.8 \%)$ strongly agreed that lack of adequate safety training expose Nurses to hazards in the Hospital, while 22 (25.3\%) agreed, 13 (14.9\%) were undecided, 16 (18.4\%) disagreed, and $4(4.6 \%)$ strongly disagreed. $10(11.5 \%)$ respondents strongly agreed that lack of knowledge/awareness on safety practices among nurses results in exposure to hazards in the Hospital, while $16(18.4 \%)$ agreed on this item, $3(3.5 \%)$ were undecided, $37(42.5 \%)$ disagreed, and $21(24.1 \%)$ strongly disagreed. 40 (46.0\%) strongly agreed that excessive workload leads to hazard in the Hospital among the Nurses, 33 (37.9\%) agreed, while 5 (5.8\%) were undecided, $1(1.1 \%)$ disagreed, and $8(9.2 \%)$ strongly disagreed. $34(39.1 \%)$ respondents strongly agreed that inadequate staff strength is a major cause hazards among the nurses, 31 (35.6\%) agreed, while $12(13.8 \%)$ were undecided, 9 (10.3\%) disagreed, and only 1 (1.1\%) respondent strongly disagreed on this item of the questionnaire. Based on these observations, the major factors associated with occupational hazard among the respondents include; insufficient 
safety gadgets and equipment in the Hospital, long working hours, lack of adequate safety training, excessive workload, and inadequate staff strength in the Hospital.

Research question 3: What is the level of practice of prevention of occupational hazards among nurses in Federal Psychiatric Hospital, Calabar?

To answer this question, items under section $\mathrm{D}$ of the questionnaire were analyzed and results presented in the table below.

Practice of prevention of occupational hazard among the respondents

S/No. Items

SA

16. Compliance with all safety instructions.

17. Adherence to infection control precautions regarding nosocomial infection.

18. Wearing safety equipment during working hours.

19. Attending workshops/seminars organised on occupational safety in the Hospital and beyond.

Options

\begin{tabular}{c|c|c|c|c} 
SA & A & D & SD & Total \\
43 & 31 & 10 & 3 & 87 \\
$(49.4)$ & $(35.6)$ & $(11.5)$ & $(3.5)$ & $(100)$ \\
30 & 40 & 9 & 8 & 87 \\
$(34.5)$ & $(46.0)$ & $(10.4)$ & $(9.2)$ & $(100)$ \\
24 & 29 & 23 & 11 & 87 \\
$(27.6)$ & $(33.3)$ & $(26.4)$ & $(12.6)$ & $(100)$ \\
25 & 19 & 29 & 14 & 87 \\
$(28.7)$ & $(21.8)$ & $(33.3)$ & $(16.1)$ & $(100)$ \\
& & &
\end{tabular}




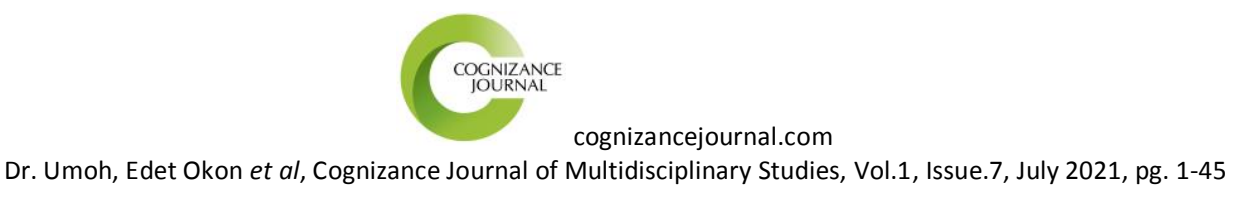

ISSN: 0976-7797

20. Reporting of unsafe situations

that are highly hazardous to

staff for quick intervention.

\begin{tabular}{c|c|c|}
18 & 28 & 29 \\
$(20.7)$ & $(32.2)$ & $(33.3)$
\end{tabular}

12

Source: Fieldwork, 2021. (Note: Nos in parenthesis are \%)

The table above shows that out of the 87 respondents, $43(49.4 \%)$ strongly agreed that they comply with all safety instructions, while 31 (35.6\%) agreed, $10(11.5 \%)$ disagreed, and $3(3.5 \%)$ strongly disagreed. $30(34.5 \%)$ respondents strongly agreed that they adhere to infection control precautions regarding nosocomial infections, 40 (46.0\%) agreed, while $9(10.4 \%)$ disagreed, and $8(9.2 \%)$ strongly disagreed. $24(27.6 \%)$ respondents strongly agreed that they wear safety equipment during working hours, while 29 (33.3\%) agreed on this item, 23 (26.4\%) disagreed, and $11(12.6 \%)$ strongly disagreed. $25(28.7 \%)$ respondents strongly agreed that they attend seminars/workshops on occupational safety in the Hospital and beyond, 19 (21.8\%) agreed, while 29 (33.3\%) disagreed, and $14(16.1 \%)$ strongly disagreed. $18(20.7 \%)$ respondents strongly agreed that they report unsafe situations that are highly hazardous to staff for quick intervention, while 28 (32.2\%) disagreed, 29 (33.3\%) disagreed, and 12 (13.8\%) strongly disagreed.

\section{Summary of respondents practice of prevention of occupational hazard $(n=87)$}

\section{Practice of prevention of occupational hazard}

Good

Poor

Total

Source: Table 4.9

\section{Frequency}

57

30

87
Percentage $(\%)$

$65.5 \%$

$34.5 \%$

$100 \%$ 
cognizancejournal.com

Dr. Umoh, Edet Okon et al, Cognizance Journal of Multidisciplinary Studies, Vol.1, Issue.7, July 2021, pg. 1-45

ISSN: 0976-7797

The table above presents the summary of the respondents' practice of prevention of occupational hazard in the Hospital. The table reveals that among the 87 respondents, $57(65.5 \%)$ had good practice of prevention of occupational hazards, while remaining proportion $30(34.5 \%)$ had poor practice of prevention of occupational hazards in the Hospital.

\section{Test of hypothesis}

$\mathrm{H}_{0}$ : There is no significant relationship between years of experience and practice of prevention of occupational hazards among nurses in Federal Psychiatric Hospital, Calabar.

$\mathrm{H}_{1}$ : There is a significant relationship between years of experience and practice of prevention of occupational hazards among nurses in Federal Psychiatric Hospital, Calabar.

Contingency Chi-square analysis showing the relationship between years of experience and practice of prevention of occupational hazard among the respondents $(n=87)$

\begin{tabular}{lcc|cccc}
$\begin{array}{c}\text { Years of } \\
\text { experience }\end{array}$ & \multicolumn{2}{c|}{ Practice of prevention } & Row total & df & Cal $\chi^{2}$ & Crit. $\chi^{2}$ \\
Good & Poor & & & & \\
$\leq 10$ years & 14 & 18 & $\mathbf{3 2}$ & & & \\
$11-20$ years & 20 & 7 & $\mathbf{2 7}$ & & & \\
$21-30$ years & 13 & 3 & $\mathbf{1 6}$ & 3 & 11.02 & 7.81 \\
Above 30 years & 10 & 2 & $\mathbf{1 2}$ & & & \\
Column total & $\mathbf{5 7}$ & $\mathbf{3 0}$ & $\mathbf{8 7}$ & & & \\
\end{tabular}




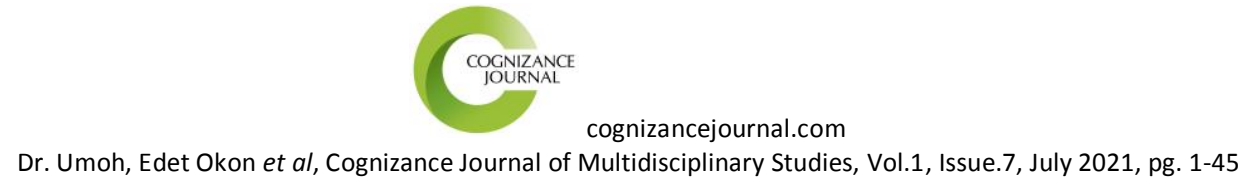

ISSN: 0976-7797

The table above shows that the calculated value of Chi-square (11.02) is greater than the critical Chi-square value (7.81) tested at 0.05 level of significance with 3 degrees of freedom. Based on the decision rule, the null hypothesis is rejected leading to a conclusion that "there is a statistically significant relationship between years of experience and practice of prevention of occupational hazards among mental health Nurses in Federal Psychiatric Hospital, Calabar.

\section{Discussion of findings}

This study was conducted to assess the prevalence of occupational hazards among mental health Nurses in Federal Psychiatric Hospital, Calabar. Findings of this study are discussed below in line with the study's objectives.

\section{Prevalence of occupational hazards and illnesses among mental health Nurses in Federal Psychiatric Hospital, Calabar}

Results of this study revealed that Nurses in the Hospital were exposed to occupational hazards and illnesses. Among the hazards the nurses are exposed to, workload was the most significant, closely followed by assaults, violence, insect bites, work accidents, and strained relationship with patients and staffs. Others were; slips/falls, exposure to contagious waste hazards, electric shocks, and injury with blood borne pathogens. Similarly, the most significant illness among the nurses due to exposure to occupational hazards is body pains. This was followed by other illnesses including; stress/psychosocial problems, back pains, sharp object injuries/cuts, sprain, neck pains, skin problems, high blood pressure, psychological problem, while least was blood borne infection. These findings are supported by findings of different authors including Chinedum et al (2016), Umoh (2020), Sabra and Morsy (2016), and Yesilgul et al (2018). These 


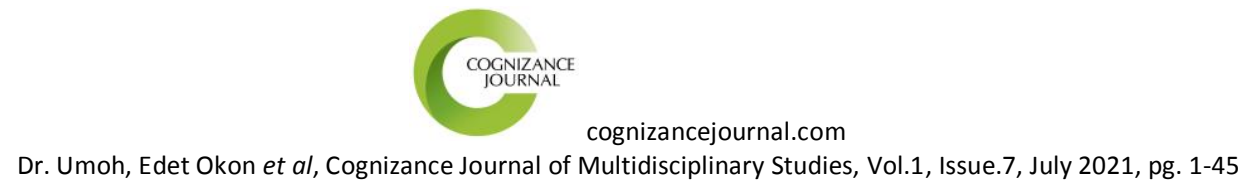

ISSN: 0976-7797

authors reported findings similar to that of the present study. For instance, Chinedum et al (2016) reported that more than $90 \%$ of the nurses have been exposed to one occupational hazard or the other, either directly or indirectly, and some of those hazards constitute to non-reported wokrelated injury, $25 \%$ of the respondent reported exposure to sharp injury while administering parenteral medications.

\section{Factors associated with occupational hazards and illnesses among mental health Nurses in Federal Neuropsychiatric Hospital, Calabar}

Results of the study revealed that most of the respondents did not agree that poor occupational health practices by nurses are a predisposing factor to occupational hazard in the Hospital. Similarly, close to half of the respondents disagreed that lack of knowledge/awareness on safety practices is associated with nurses' exposure occupational hazards in the Hospital. On the other hand, many of the respondents belief that insufficient safety gadgets and equipments predispose nurses to occupational hazards. Other factors associated with occupational hazards as perceived by the respondents were; long working hours, lack of adequate staff training, excessive workload, and inadequate staff strength. According to the respondents' perception, the most significant predisposing factor to occupational hazard in the Hospital among Nurses was excessive workload. This finding is supported by findings of Scozzafave et al (2019 who reported that insufficient academic training, lack of preparation and maintenance of equipment; poor relationship with colleagues; shortage of human resources and lack of capacity building; conflict between the demands of the home and work, were factors associated psychosocial risks among nurses in a psychiatric hospital in Brazil. Similarly, Rajan (2016) found that nurses 


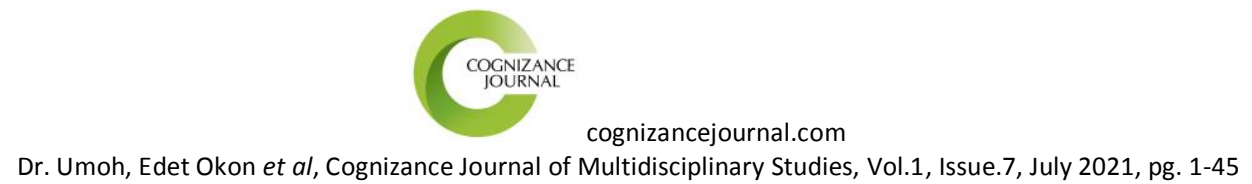

ISSN: 0976-7797

working in a Medical College Hospital in Thiruvananthapuram reported workload, lack of adequate staff and lack of good assistive devices as factors associated occupational hazards. This is in support of the findings of the present study.

\section{Level of practice of prevention of occupational hazards among nurses in Federal}

\section{Psychiatric Hospital, Calabar}

Finding of the study revealed that nearly half of the respondents agreed strongly that they comply with all safety instructions, and most of them also agreed that they adhere to infection control precautions regarding nosocomial infections. Majority agreed that they wear safety equipment during working hours; while majority agreed that they report unsafe situations that are highly hazardous to staff for quick intervention to avoid occurrence of hazards; and most of the respondents agreed that they attend seminars/workshops on occupational safety organized in the Hospital and beyond. In summary, results of the study revealed that a little more than half of the respondents, exhibit good practice of prevention of occupational hazard in the Hospital. This finding is supported by findings as reported by Umoh (2020). The author reported that to prevent exposure to hazards, healthcare providers including Nurses in Federal Psychiatric Hospital, Calabar adhered to safety practices such as compliance with infection control precautions regarding blood, body fluids and infectious tissues; wearing of safety equipment during working hours; and reporting of unsafe situations that are highly hazardous to staff for quick response. Also, Ogunnaike and Akinwaare (2020) reported good preventive practice of occupational hazards among nurses in a Tertiary Health Institution in Nigeria which also agrees with findings of the present study. 


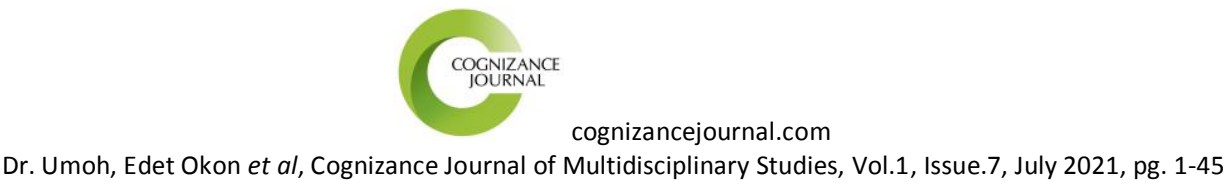

ISSN: 0976-7797

\section{Relationship between years of work experience and preventive practices among Nurses in}

\section{Federal Psychiatric Hospital, Calabar}

The relationship between years of work experience and practice of prevention of occupational hazards among the respondents was tested using Chi-square statistical analysis with a significant level set at 0.05 . Findings of this test revealed a calculated Chi-square value which is greater than the critical Chi-square value tested at the stipulated level of significance with its associated degree of freedom. In consonance with the decision rule, the null hypothesis was rejected. This led to the conclusion that, there is a statistically significant relationship between years of experience and practice of prevention of occupation hazards among mental health Nurses in Federal Psychiatric Hospital, Calabar.

\section{Summary of findings}

The main aim of this study was to assess the prevalence of occupational hazards and illnesses among mental health Nurses in Federal Psychiatric Hospital, Calabar. Summary of the study's findings is as follows:

1. Most of the respondents used for this study were; female, aged 31-40 years, married, Christians, Nursing Officer II, and had 11-20 years of experience.

2. The most prevalent occupational hazards among the nurses were excessive workload, assaults, and violence. While the most prevalent occupational illnesses were body pain, stress/psychosocial problems, and back pain.

3. Significant factors associated with incidence of occupational hazards and illnesses in the Hospital include: insufficient safety gadgets and equipment in the Hospital, long working 


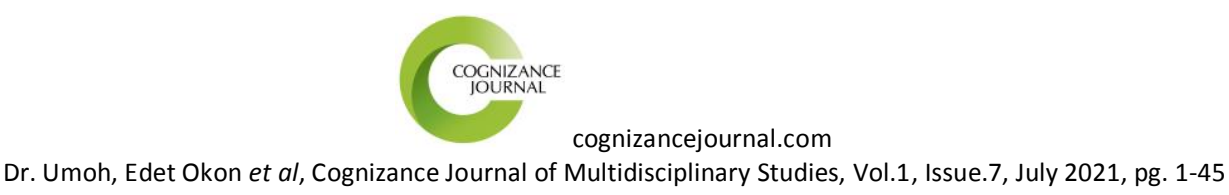

hours, lack of adequate safety training, excessive workload, and inadequate staff strength in the Hospital.

4. Nurses in Federal Psychiatric Hospital have good practice of prevention of occupational hazards.

5. There is a significant relationship between years of experience and practice of prevention of occupational hazards among nurses in Federal Psychiatric Hospital, Calabar.

\section{CONCLUSION AND RECOMMENDATIONS}

\section{Implication of the study}

This study revealed that nurses have good practice of prevention of occupational hazard in the Hospital. This practice is significantly influenced by the nurses' years of work experience. Therefore, newly employed nurses should learn to emulate the attributes of nurses who are older in the Hospital. This will help them improve their performance especially when it comes to prevention of occupational hazards. In addition, nurses who have accumulate wealth of experience while working in the Hospital should organize frequent seminars and lectures to newly employed nurses to boost their knowledge and improve practice of prevention of occupational hazards.

\section{Recommendations}

Based on the findings of this study, it is recommended that:

1. Nurses should erase the notion that the use of personal protective equipment will affect the ability to do their work effectively. 


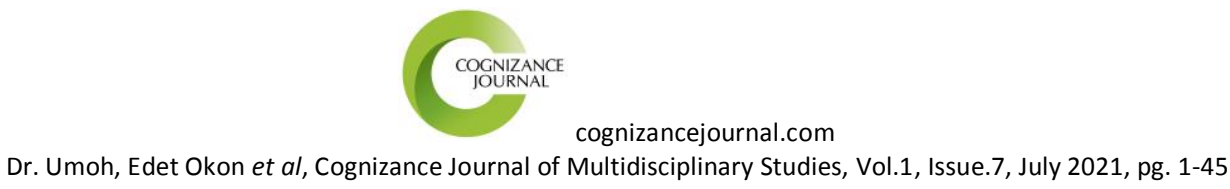

2. Management of the Hospital should ensure that equipment and safety gadgets are not only available but should also be adequately distributed to all the Wards/Units in the Hospital to aid adherence to infection control practices among nurses in the Hospital.

3. Strict policies on safety practices should be maintained and compliance ensure through adequate supervision to avoid nurses' exposure to hazards.

4. Government should liaise with the Hospital management to review working hours and make policies that will benefit the Nurses.

5. Government should embark on recruitment of more Nurses to reduce work load and enhance compliance to infection control practices in the Hospital.

6. The Hospital environment should be conducive for the use of safety equipment by the Nurses.

7. Nurses should be trained and re-trained on the use of safety equipment to avoid exposure to hazards.

\section{Suggestions for further study}

The researcher suggests that further study on this topic should be carried out in other health care facilities to compare with the results of this study, and new variables should be introduced in order to evaluate the degree to which nurses adhere to infection control practices for the prevention of occupational hazards in the Hospital.

\section{Conclusion}

In line with findings of this study, it is concluded that Nurses in Federal Neuropsychiatric Hospital, Calabar are exposed to hazards and illnesses in the Hospital. Prominent among these hazards include; excessive workload, assaults and violence; while most significant illnesses 


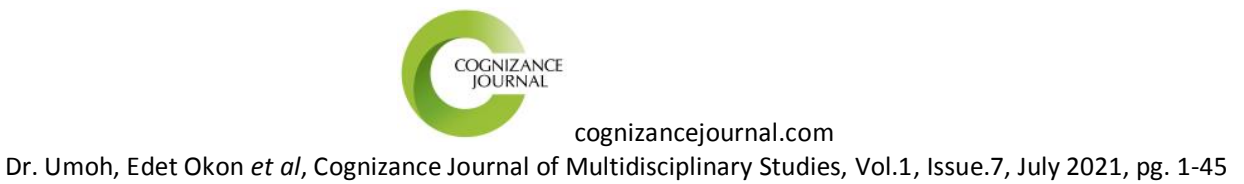

ISSN: 0976-7797

resulting from exposure to hazards among the nurses were; body pains, stress/psychosocial problems, and neck pains. Factors associated with incidence of these hazards as perceived by the Nurses are; insufficient safety gadgets and equipment in the Hospital, long working hours, lack of adequate safety training, excessive workload, and inadequate staff strength in the Hospital. There is good practice of prevention of occupational hazards among nurses, and this practice is significantly influenced by the years of experience of nurses in the Hospital.

\section{REFERENCES}

[1]. Agbana, B. E., Oladele, A. J., Daikwo, M. A., \&Olufunto, M. L. (2016). Knowledge of Occupational Hazards Among Sawmill Workers in Kwara State, Nigeria, Nigerian Postgraduate Medical Journal, 25-32. http://doi.org/10.4103/1117-1936.180176.

[2]. Aluko, O.O., Adebayo A.E., Adebisi T.F., Ewegbemi, M. K., Abidoye A.T., and Popoola, B.F. (2016) Knowledge, attitudes and perception of occupational hazards and safety practices in Nigerian healthcare workers. BioMed Central Research Notes 9:71

[3]. Amosun, A. M., Degun, A. M., Atulomah, N.O.S., Olarenwaju, M.F. \&Aderibigbe, K.A. (2017). Level of knowledge regarding occupational hazards among nurses in Abeokuta, Ogun state, Nigeria. Current Research Journal Biological Sciences. 3(6):586-590.

[4]. Awodele, O., Papoola, T., Ogbudu, B., Akinyede, A., Coker, H. \&Akintowa, A. (2014). Occupational Hazards and Safety Measures Amongst the Paint Factory Workers in Lagos, Nigeria. Saf Health Work. 2014 Jun; 5(2): 106-111. Published online 2014 Apr 4. doi: 10.1016/j.shaw.2014.02.001

[5]. Ayalu A, Reda SB, Amae D, Alemayehu A, Belachew T, Tiyou A, Deribe K. (2017). Knowledge and attitudes of caregivers of HIV-infected children towards antiretroviral treatment in Ethiopia. Patient Educ Couns;85(2):89-94.

[6]. Bell, J. L., Collins, J. W., Tiesman, H.M., Ridenour, M., Konda, S, Wolf, L. \&Evanoff B.(2013). Slip, trip and fall injuries among nursing care facility workers. Workplace Health Safety. 61 (4): 147-152.

[7]. Caruso CC. Negative Impact of Shift work and Long work Hours. RehabilNurs. 2014;39(1);16-25.

[8]. Centers for Disease Control and Prevention (2016), 800-CDC-INFO NCEH/EHHE,

[9]. Department of Health and Human Services, National Institute for Occupational Safety and Health. NIOSH Alert: Preventing needle stick injuries in healthcare settings. 2018. http://www.cdc.gov/niosh/docs/2000-108/ (accessed 7/1/2021).

[10].Elewa, A. H., \&Aly El Banan, S. H. (2016). Occupational hazards as perceived by Nursing Interns and protective measures. IORS Journal of Nursing and Health Science, 5 (6): 107-118.

[11].Eljedi, A. (2015). Prevalence and response to occupational hazards among Nursing Students in Gaza Strip, Palestine: The Role of Personal Protective Equipment and Safety Regulations. Public Health Research, 5 (1): 32-38. 


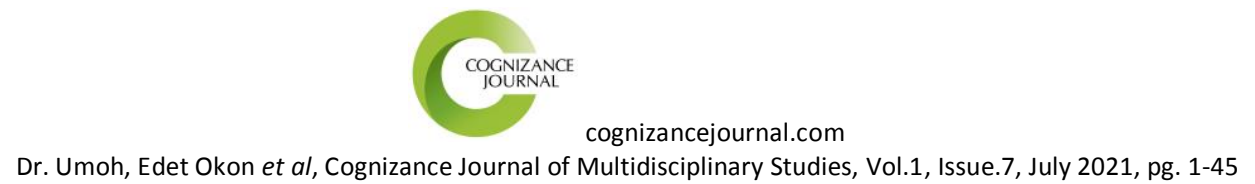

[12].Fasunloro A, Owotade FJ. (2004) Occupational hazards among clinical dental staff. $J$ Contemporary Dental Pract 5(2):134-52.

[13].Ford MT \&Tetrick LE (2011). Relations among occupational hazards, attitudes, and safety performance. J Occup Health Psychol. 2011;16(1):48-66.

[14].Gold, Julian, Maggy Tomkins, Phillip Melling, and Nicholas Bates. (2004). Guidance note on health care worker safety from HIV and other blood borne infections. HNP Discussion Paper. Washington, DC:

[15].Houtman, Irene, Karin Jettinghoff, and Leonor Cedillo. (2007). Raising awareness of stress at work in developing countries: A modern hazard in a traditional working environment: Advice to employers and worker representatives. Protecting Workers' Health Series no. 6. Geneva, Switzerland: World Health Organization. http://www.who.int/occupational_health/publications/raisingawarenessofstress.

[16].International Labour Organization (ILO) (2018). Standards-related activities in the area of occupational safety and health. International labour conference 91 st session.

[17].International Labour Organization (ILO), (1996-2016). www.ILO.org/globalstandard standards/-by-international-labour-workrelatedaccidents

[18]. Irtyah M, Lamia B, Ahlem M, et al. Influence of shift work on the physical work capacity of Tunisian nurses: a cross-sectional study in two university hospitals. Pan Afr Med J. 2017;26:59.

[19].Isara A.R. \&Ofili A.N. (2012): Prevalence of Occupational Accidents/Injuries among Health care Workers in a Federal Medical Centre in Southern Nigeria. West Afr J Med., Jan-Mar; 31(1): Pp. 47:51.

[20].Lipscomb J, Rosenstock L. (2012). Healthcare workers: Protecting those who protect our health. Infection Control and Hospital Epidemiology, 18(6):397-399.

[21].Lugah, V., Ganesh, B., Darus, A., Retneswari, M., Rosnawati, M. R., \&Sujatha, D. (2010). Training of occupational safety and health: knowledge among healthcare professionals in Malaysia, PubMed Commons, 51(7), 586-591. https://www.ncbi.nlm.nih.gov/pubmed/20730400.

[22].NCEH Pub. No.02-0750 MS F52 cdcinfo@cdc.gov 4770 Buford Hwy, Atlanta, GA 30341 http://www.cdc.gov/nceh/ehhe

[23].Niu, S. (2010). Senior Occupational Health Specialist. International Labour Office 4, route des Morillons 1211 Geneva 22. Switzerland in African Newsletter on occupational health and safety; Health care workers, Volume 20.

[24].Ochei, K. C., Obeagu, E.I., Ogobo, E.E., Omo-Emmanuel, U.K., \&Odo, M. (2016). Occupational exposure of nurses to hazards in workplace in Cross River State, Nigeria. Journal of Biological and Chemical Research, 33 (1): 279-287.

[25].Ogunnaike, S.M. \&Akinwaare, M.O. (2020). Occupational hazard preventive measures among Nurses in a Nigerian Tertiary Health Institution. Nursing \& Care Open access Journal, 7 (1): 20-25.

[26]. Oluwagbemi, B. (2011) Themes and issues in occupational health and safety, 2nd edition, Bangalore :Vertext Media Ltd.

[27].Rajan, D., (2016) . Occupational Hazards And Health: A Comparative Study Among Medical Laboratory Technicians. InternationalJournal For Research In Applied Science And Engineering Technology (I Jraset). Vol. 2 Issue Vii. 


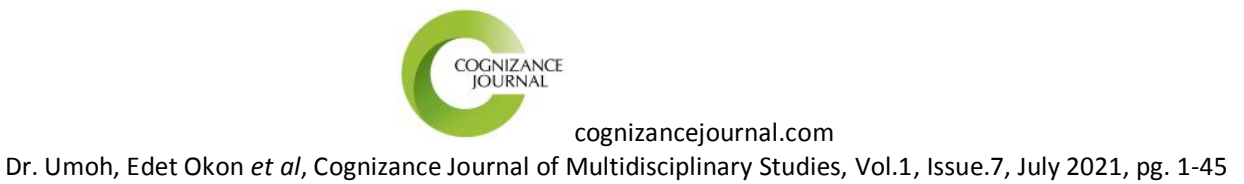

[28].Sabra, H. E., \&Morsy, S. M. (2016). Occupational Health Hazards among Nurses at Quena University Hospital. IOSR Journal of Nursing and Health Science, 5 (3): 28-34.

[29].Scozzafave, M.C.S., Leal, L.A., Soares, M.I., \& Henrique, S. H. (2019). Psychosocial risks related to the Nurse in the Psychiatric Hospital and management strategies. Rev Bras Enferm, 72 (4): 834-40.

[30].Senthil A, Anandh B, Jayachandran P, Thangavel G, Josephin D, Yamini R, Kalpana B (2014): Perception and prevalence of work-related health hazards among health care workers in public health facilities in southern India. Int J Occup Environ Health, 8: 177185.

[31].Smith. Musculoskeletal disorder among hospital Nurses in rural Japan. Rural Remote Health. 2007;3(3):241

[32].Umoh, E.O. (2020). Occupational Risk and Hazards among Nurses and Health workers in Federal Psychiatric Hospital, Calabar. International Journal of Research and Innovation in Social Science, 4 (12).

[33].WHO (2007). Raising Awareness of Stress at Work in Developing Countries Protecting Workers' Health Series No. 6; WHO Press, Geneva, Switzerland. http://www.who.int/occupational_health/publications/pwh6.

[34]. World Health Organization (2006) Health workers: A global profile [Online] Available at www.who.int/whr/2006/06_chap1_en.pdf Assessed [12/01/2021].

[35].Yesilgul, G., Cicek, H. S., Avci, M. Z., \&Huseyniklioglu, B. (2018). Nurses' knowledge level and perceptions regarding occupational risks and hazards. International Journal of caring sciences, 11 (2): 1117.

\section{APPENDIX 1}

\section{QUESTIONNAIRE}

Questionnaire on prevalence of occupational hazard among Mental Health Nurses in Federal Neuropsychiatric Hospital - Calabar

\section{Dear Respondent,}

Department of Science \& Technology

Nursing Science

National Open University

I am a final year student of the above named Institution carrying out a study on the topic stated above. You are kindly requested to tick $(\sqrt{ })$ from the options that are provided. Your response will be treated with utmost confidentiality; hence your name is not required, thank you.

\section{SECTION A: SOCIO-DEMOGRAPHIC DATA}

1. Gender: Male [ ] Female [ ]

2. Age: $\leq 20 \mathrm{yrs}[$ ] $21-30 \mathrm{yrs} \mathrm{[} \mathrm{]} 31-40 \mathrm{yrs}$ [ ] $41-50 \mathrm{yrs}$ [ ] Above $50 \mathrm{yrs}[$ ] 


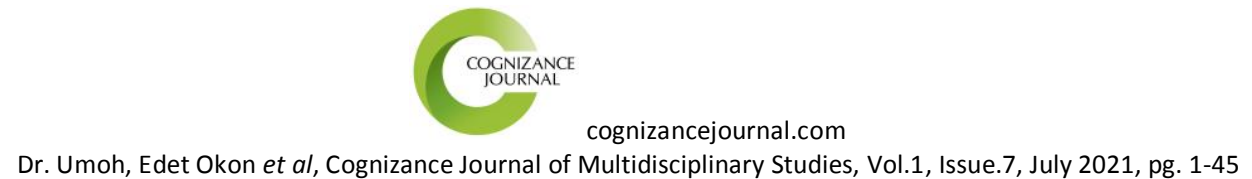

3. Marital status: Single [ ], Married [ ], Separated [ ], Divorced [ ] Widow [ ]

4. Religion: Muslim [ ], Christianity [ ], Traditional [ ]

5. Rank: NO II [ ] NO I [ ] SNO [ ] PNO [ ] ACNO [ ] CNO [ ]

6. Years of experience: $\leq 10 \mathrm{yrs}$ [ ] $11-20 \mathrm{yrs}$ [ ] 21 - 30yrs [ ] Above 30yrs [ ]

\section{SECTION B: Prevalence of occupational hazard/illnesses}

Please tick $[\sqrt{ }]$ any of the two (2) options (Yes or No) that is most applicable to you.

S/No

Options

7. Which of the under listed risks and/or hazards have you Yes No experienced during your routine work in the hospital?

Slips/falls

Working accidents

Insects and animal bites

Violence and assaults

Injury with blood borne pathogen

Contagious waste hazard

Chemical splash

Burns from fire outbreak

Confined space

Electric shock

Strained relationship with patients and staffs

Work overload 
cognizancejournal.com

Dr. Umoh, Edet Okon et al, Cognizance Journal of Multidisciplinary Studies, Vol.1, Issue.7, July 2021, pg. 1-45

ISSN: 0976-7797

\section{Occupational injury and disease}

8. Which of the following health problems have you had as a result of your exposure to hazards in the Hospital?

Back pain

Neck pain

Body pain

Sharp object injuries/cuts/fractures

Sprain

Skin problems

Varicosis (lower extremity)

Psychological problem

Blood born infection

Stress/psychosocial problems

High blood pressure

Others 


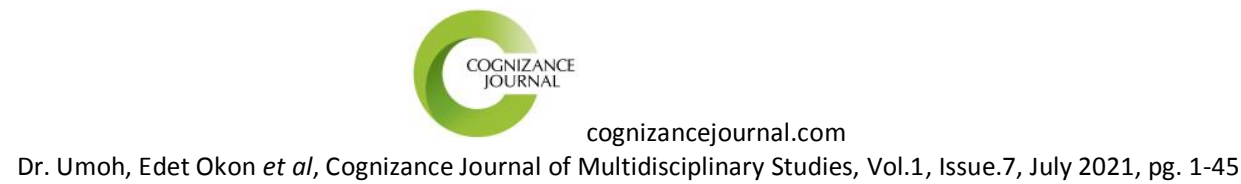

ISSN: 0976-7797

SECTION C: Factors associated with occupational hazards in Federal Psychiatric Hospital, Calabar

Please tick $[\sqrt{ }]$ the column that best describe your opinion. The options are as follows: $\mathrm{SA}=$ Strongly Agree, A = Agree, D = Disagree, SD = Strongly Disagree, U= Undecided

\begin{tabular}{|c|c|c|c|c|c|c|}
\hline $\mathbf{S} / \mathbf{N}$ & Factors associated with occupational hazards & SA & $\mathbf{A}$ & $\mathbf{D}$ & SD & $\mathbf{U}$ \\
\hline & $\begin{array}{l}\text { In your opinion, which of the underlisted are the factors } \\
\text { associated with health hazards in the Hospital? }\end{array}$ & & & & & \\
\hline 9 & Poor occupational health practices by nurses. & & & & & \\
\hline 10. & Insufficient safety gadgets and equipment in the Hospital. & & & & & \\
\hline 11 & Long working hours. & & & & & \\
\hline 12. & Lack of adequate safety training. & & & & & \\
\hline 13. & Lack of knowledge/awareness regarding safety practices. & & & & & \\
\hline 14. & Excessive Workload & & & & & \\
\hline 15. & Inadequate staff strength & & & & & \\
\hline
\end{tabular}

\section{SECTION D: Practice of prevention of occupational hazards in Federal Psychiatric} Hospital, Calabar

Please tick $[\checkmark]$ any of the options that you employ in order to prevent the occurrence of hazards in the Hospital. The options are as follows: $\mathrm{SA}=$ Strongly Agree, $\mathrm{A}=$ Agree, $\mathrm{D}=$ Disagree, $\mathrm{SD}=$ Strongly Disagree.

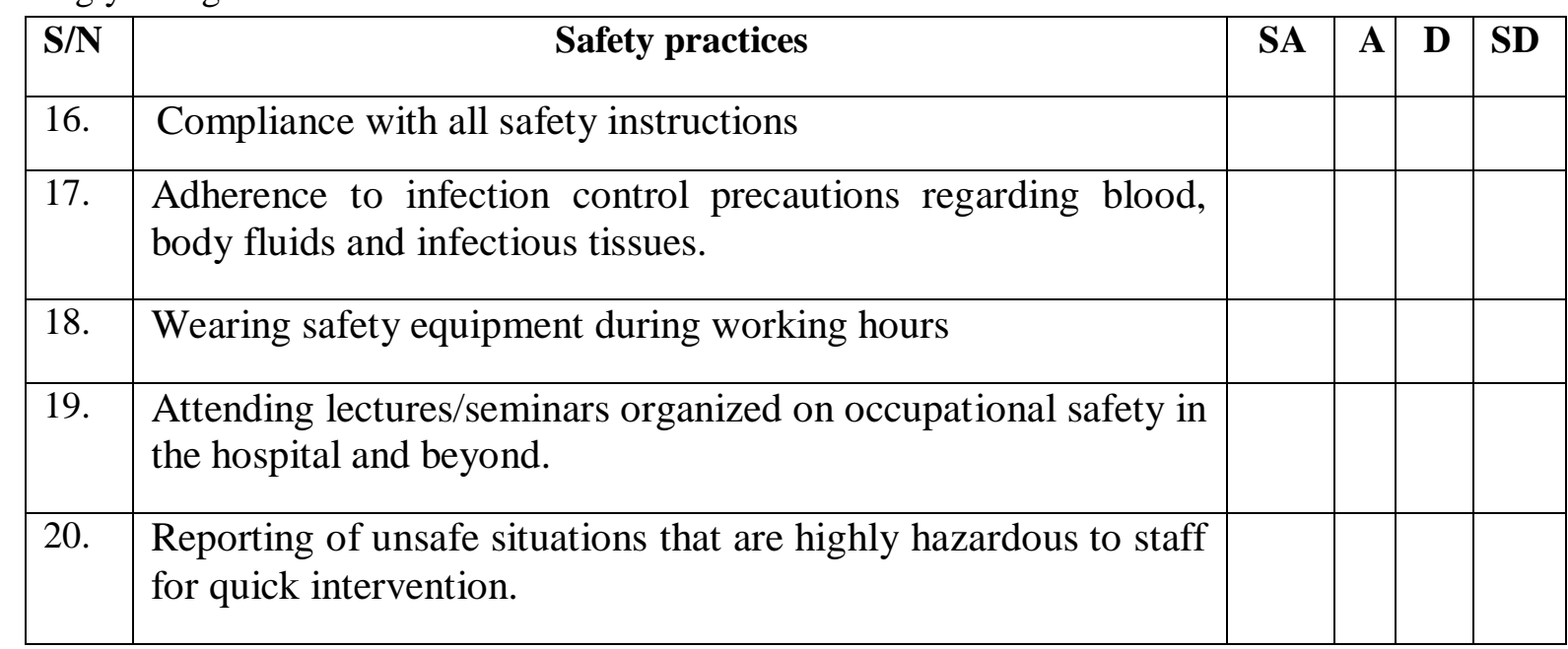




\section{APPENDIX 2}

\section{(RELIABILITY ANALYSIS)}

\section{Correlations}

\begin{tabular}{|rl|r|r|}
\hline & & \multicolumn{1}{|c|}{ Test1 } & \multicolumn{1}{c|}{ Retest1 } \\
\hline \multirow{4}{*}{ Test1 } & Pearson Correlation & 1 & $.929^{* *}$ \\
& Sig. (2-tailed) & & .000 \\
& $\mathrm{~N}$ & 10 & 10 \\
& Pearson Correlation & $.929^{* *}$ & 1 \\
\multirow{3}{*}{ Retest1 } & Sig. (2-tailed) & .000 & \\
& $\mathrm{~N}$ & 10 & 10 \\
\hline
\end{tabular}

${ }^{* *}$. Correlation is significant at the 0.05 level (2-tailed).

\begin{tabular}{|rl|r|r|}
\hline \multicolumn{2}{c|}{ Correlations } \\
\hline \multirow{4}{*}{ Test2 } & \multicolumn{1}{|c|}{ Test2 } & Retest2 \\
& Pearson Correlation & 1 & $.965^{* *}$ \\
& Sig. (2-tailed) & & .000 \\
& $\mathrm{~N}$ & 10 & 10 \\
& Pearson Correlation & $.965^{* *}$ & 1 \\
Retest2 & Sig. (2-tailed) & .000 & \\
& $\mathrm{~N}$ & 10 & 10 \\
\hline
\end{tabular}

**. Correlation is significant at the 0.05 level (2-tailed).

\section{Correlations}

\begin{tabular}{|rl|r|r|}
\hline & & \multicolumn{1}{|c|}{ Test2 } & Retest2 \\
\hline \multirow{4}{*}{ Test2 } & Pearson Correlation & 1 & $.918^{* *}$ \\
& Sig. (2-tailed) & & .000 \\
& $\mathrm{~N}$ & 10 & 10 \\
& Pearson Correlation & $.918^{* *}$ & 1 \\
Retest2 & Sig. (2-tailed) & .000 & \\
& $\mathrm{~N}$ & 10 & 10 \\
\hline
\end{tabular}

**. Correlation is significant at the 0.05 level (2-tailed). 


\section{FEDERAL NEURO-PSYCHIATRIC HOSPITAL}

123 CALABAR ROAD,

PMB 1052, CALABAR. CROSS RIVER STATE, www.fnphcalabar.gov.ng

Acting Board Chairman

Mr. Kunle M. Dada

Email: Kunledada@yahoo.com

Head of Administration/Secretary to Board

Ekanem G. Davis (Mrs.)

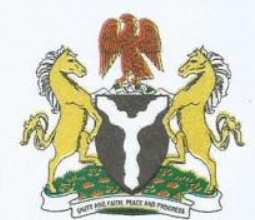

Medical Director

Dr. Bassey Edet

MBBCh, FMCPsych, FIMC, IFA

GSM: 08037192240

Email: drbasseyedet@gmail.com

B.A. (Hons.), PGDM, MBA, AIHSAN, FIPM, ACIPM

Acting Head Clinical Services

Dr. Theo Osim Onyuku

GSM: 08033509759

Email: ekanemdavis@yahoo.com

MBBS (UNN) MWACPsy., FMCPsych

Email: dronyuku@gmail.com

Our Ref:...HREC/01/.025

$30^{\text {Th }}$ march, 2021

Iwok, Enewan Udofia

National Open University

Calabar Center

Calabar.

Sir/Madam,

\section{ETHICAL APPROVAL}

\section{RE:" PREVALENCE OF OCCUPATIONAL HAZARDS AMONG MENTAL HEALTH NURSES IN FEDERAL NEURO-PSYCHIATRIC HOSPITAL CALABAR."}

We wish to inform you that the Research Ethics Committee has approved your Research Proposal titled: "prevalence of occupational hazards among mental health nurses in federal neuro-psychiatric hospital calabar"under the supervision of Dr. Umoh, Edet Okon of the National Open University.

It is recommended that you share relevant findings of your research with the study Institution.

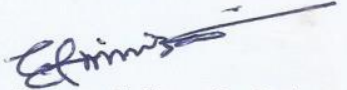

Barr. Edim 0. Odey

Secretary HREC (FNPH-Cal) 